\title{
Behaviour of MH silts with varying plasticity indices
}

Steven T. Y. Wong BEng(Hons)

Research Scholar, Research Centre for Sustainable Technologies, Faculty of Engineering, Science and Computing, Swinburne University of Technology Sarawak Campus, Kuching, Malaysia
Dominic E. L. Ong BE(Hons), PhD, PEng, MIEM CPEng, MIEAust Associate Professor and Director, Research Centre for Sustainable

Technologies, Faculty of Engineering, Science and Computing, Swinburne University of Technology Sarawak Campus, Kuching, Malaysia (corresponding author: elong@swinburne.edu.my) (Orcid:0000-0001-8604-8176)

Retnamony G. Robinson BEng(Hons), MSc, PhD

Professor, Civil Engineering Department, Indian Institute of Technology Madras, Chennai, India

It is important for geotechnical engineers to understand the intrinsic and mechanical behaviour of silt as it is presently recognised that there exist gaps in understanding its fundamental behaviour. The behaviour of kaolin samples with varying clay and silt contents was investigated in the present study. This study characterised the samples by their corresponding ranges of plasticity index $\left(P_{1}\right)$ - namely, $P_{1} \leq 13 \%$ and $P_{1}>13 \%$. This outcome is achieved by interpreting the results of Atterberg limit tests, particle size analysis, isotropically consolidated undrained triaxial tests and oedometer tests carried out on the kaolin samples with $P_{1}$ between 7 and $16 \%$. The results obtained in this study show good reliability when compared to 65 sets of past significant experimental studies derived from 33 established past research papers.

\section{Notation}

$A_{\mathrm{c}} \quad$ activity

e void ratio

$\mathrm{C}_{\mathrm{L}} \% \quad$ clay content

$\mathrm{CL} \quad$ low plasticity clay

$\mathrm{CH}$ high plasticity clay

$L_{\mathrm{L}} \quad$ liquid limit

M slope of the critical-state line (CSL)

MH high-plasticity silt

ML low-plasticity silt

$O_{\mathrm{CR}} \quad$ overconsolidation ratios

$p^{\prime}$

$p_{\mathrm{c}}^{\prime}$

$P_{\mathrm{I}}$

$P_{\mathrm{L}}$

$q$

$q_{\mathrm{f}}$

$u_{\mathrm{f}}$

$v$

$\Delta \sigma_{1}$

$\Delta \sigma_{1}^{\prime}$

$\Delta \sigma_{3}$

$\Delta \sigma_{3}^{\prime}$

$\Delta u$

$\varepsilon_{\mathrm{f}}$

$\kappa$

$\lambda$

$\lambda_{\mathrm{CSL}}$

$\lambda_{\mathrm{NCL}}$

$\lambda_{\mathrm{NCL}} / \lambda_{\mathrm{NCL}}$ ratios of the gradients of compression lines

$\sigma_{1} \quad$ total vertical stress

$\begin{array}{ll}\sigma_{1}^{\prime} & \text { effective vertical stress } \\ \sigma_{1}^{\prime} / \sigma_{3}^{\prime} & \text { maximum principal stress ratio } \\ \sigma_{3} & \text { total confining pressure } \\ \sigma_{3}^{\prime} & \text { effective confining stress } \\ \phi^{\prime} & \text { effective angle of shearing resistance friction }\end{array}$

\section{Introduction}

Based on particle size and plasticity characteristics, soils are classified as sand, silt and clay. The behaviours of sand and clay are unique. However, the behaviour of silts lies in between the behaviours of clays and sands. Some silts behave more like sand, and some others more like clay depending on their basic characteristics. It is essential to identify silts behaving as sand-like or clay-like. Boulanger and Idriss (2006) found that sand-like (behaving more fundamentally as sand) and clay-like soils (behaving more fundamentally as clay) have some fundamental differences in terms of stress-strain behaviour, compressibility and the slope of the critical-state line (CSL) in the $e-\ln p^{\prime}$ space against the slope of the normally consolidated line (NCL). The major observations of Boulanger and Idriss (2004) include the following.

(a) Sand-like materials exhibit different slopes for the CSL and NCL, while clay-like materials show a similar slope for the CSL and NCL in the $e-\ln p^{\prime}$ space.

(b) The effective stress paths of sand-like materials in undrained monotonic shearing show an initially contractive response (positive pore pressure increments) followed by a transition to an incrementally dilative response (decreases in pore pressure).

(c) Sand-like materials have little compressibility such that their void ratio does not change significantly as the effective consolidation stress is increased, while clay-like materials are relatively more compressible. 
In a subsequent study, Boulanger and Idriss (2006) proposed that materials with $P_{\mathrm{I}}$ less than $7 \%$ would have a sand-like behaviour, while materials with $P_{\mathrm{I}}$ greater than or equal to $7 \%$ would exhibit a clay-like behaviour. In addition, it was also described that finegrained soils with $P_{\mathrm{I}}$ values between 3 and $6 \%$ may exhibit a transitional behaviour. As a result, an appropriate procedure for examining the liquefaction resistance of soils was developed based on the behaviour of the materials. Boulanger and Idriss (2006) stated that the Atterberg limits tests are more reliable than particle size analysis, particularly for clays (i.e. $<2 \mu \mathrm{m}$ ), in order to correlate to the stress-strain characteristics of soils and also to differentiate between clay-like and sand-like behaviours.

It is also vital to note that Ferreira and Bica (2006) reported that transitional soils with particle size distributions between those of clean sands and plastic clays develop their own respective unique NCL and CSL and are not in accordance with the critical-state framework described for either sands or clays. In a research study, Nocilla et al. (2006) recommended identifying a new framework to describe the behaviour of silts in the transitional form. Such a framework has yet to be identified or developed due to the behaviour of silt being perhaps more complex than those of sand and clay.

Much research has been reported on low-plasticity silt (ML), with a liquid limit $\left(L_{\mathrm{L}}\right)$ lower than $50 \%$ - namely, by Wang and Luna (2012), Boulanger and Idriss (2006), Nocilla et al. (2006) and Hyde et al. (2006). They dealt with the characterisation and/or mechanical properties of ML. However, it was observed that very limited studies have been carried out to understand the behaviour of high-plasticity silts $(\mathrm{MH})$ with a liquid limit higher than $50 \%$. In this research, MH silts with $L_{\mathrm{L}}$ that ranges from 52 to $64 \%$ were tested, and the results are reported.

Nocilla et al. (2006) investigated the behaviour of Italian silt with a plasticity index $\left(P_{\mathrm{I}}\right)$ of $12 \%$ and found that as the clay contents reduce, the behaviour of silt changes from a clay-like behaviour to a transitional form demonstrating behaviours between those of clays and clean sands. For this situation, the silt in the transitional form demonstrates neither a unique NCL behaviour nor any unique CSL behaviour. Hyde et al. (2006) reported that the mechanical properties of low-plasticity silt with $P_{\mathrm{I}}$ of $6 \%$ were sand-like. Furthermore, Wang and Luna (2012) characterised the lowplasticity Mississippi River Valley (MRV) silt with $P_{\mathrm{I}}$ of $6 \%$ by using triaxial compression tests with different overconsolidation ratios $\left(O_{\mathrm{CR}}\right)$ of 1,2 and 8 and reported that no unique critical state could be observed. The CSL in the void ratio (e) against the logarithm of mean effective normal stress $\left(p^{\prime}\right)$ space was not parallel to the normal consolidation curve, thus possibly indicating a sand-like behaviour. Ladd et al. (1977) as cited by Wang and Luna (2012) stated that deviator stress of some clays can be normalised by the effective consolidation pressure. The deviator stresses of the MRV silts with different $O_{\mathrm{CR}}$ values were normalised by the effective consolidation pressures, after which the results indicated that the MRV silts had a unique clay-like behaviour. The method identified by Boulanger and Idriss (2006) for distinguishing between sand-like and clay-like behaviours has worked well on both low-plasticity (ML) silts presented by Nocilla et al. (2006) and Wang and Luna (2012). Nonetheless, Wang and Luna (2012) likewise reported that the work of Boulanger and Idriss (2006) did not capture the effect of $O_{\mathrm{CR}}$ on silt behaviour.

As such, it is envisaged that the work of Boulanger and Idriss (2006) can be further refined to accommodate a larger variety of soils that include high-plasticity silts $(\mathrm{MH})$. In the present study, the authors carried out a series of experiments on four types of kaolin samples with different particle size distributions and plasticity values. The results are analysed along with the data presented in the literature so as to identify the clay-like and sand-like behaviours.

\section{Laboratory testing programme}

\section{Material description}

Four types of commercially available kaolin powder with varying clay contents - namely KM20, KM25, KM35 and KM55 - were

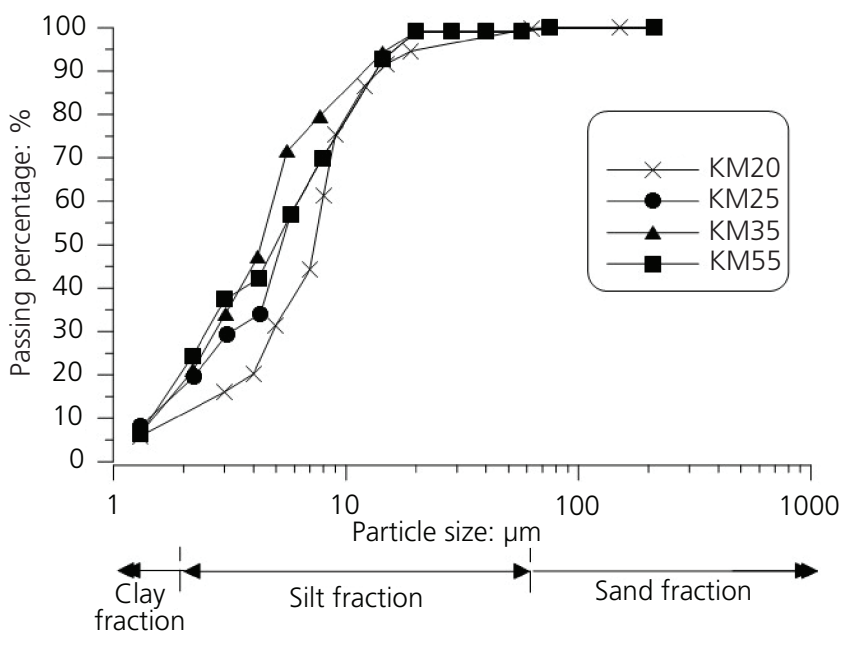

Figure 1. Particle size distribution of kaolinite samples

Table 1. Gradation, $L_{L}, P_{L}$ and $P_{1}$ values of the kaolin samples

\begin{tabular}{lcccccccc} 
Sample & $\begin{array}{c}\text { Sand } \\
\text { fraction: } \%\end{array}$ & $\begin{array}{c}\text { Silt } \\
\text { fraction: } \%\end{array}$ & $\begin{array}{c}\text { Clay } \\
\text { fraction: \% }\end{array}$ & $\boldsymbol{L}_{\mathrm{L}}: \%$ & $\boldsymbol{P}_{\mathrm{L}}: \%$ & $\boldsymbol{P}_{\mathbf{l}}: \%$ & $\begin{array}{c}\text { Soil } \\
\text { classification }\end{array}$ & $\begin{array}{c}\text { Activity }=\boldsymbol{P}_{\mathbf{I}} / \text { clay content\% } \\
\text { (Skempton, 1953) }\end{array}$ \\
\hline KM20 & 4.44 & 84.61 & 10.95 & 52 & 44 & 7 & $\mathrm{MH}$ & 0.66 \\
KM25 & 0.88 & 79.62 & 19.50 & 59 & 48 & 11 & $\mathrm{MH}$ & 0.55 \\
KM35 & 0.88 & 78.00 & 21.12 & 62 & 46 & 16 & $\mathrm{MH}$ & 0.77 \\
KM55 & 0.88 & 74.75 & 24.38 & 64 & 49 & 15 & $\mathrm{MH}$ & 0.62
\end{tabular}


Behaviour of $\mathrm{MH}$ silts with varying

plasticity indices

Wong, Ong and Robinson

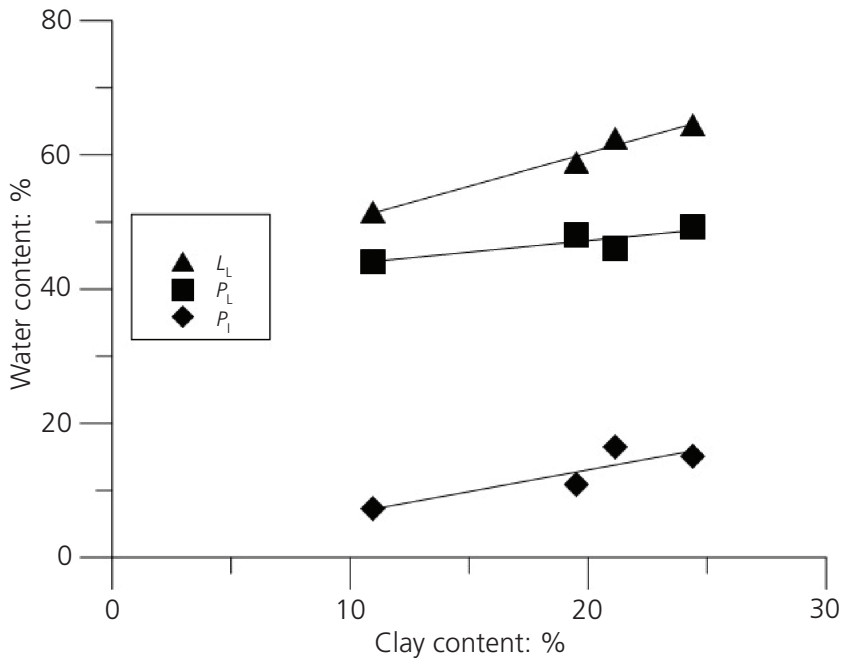

Figure 2. Linear relationship between clay contents and $L_{\mathrm{L}}, P_{\mathrm{L}}$ and $P_{1}$ of kaolin samples

utilised to set up the reconstituted kaolin samples. The kaolin was mined at depths between 4.5 and $6.0 \mathrm{~m}$ below the ground. Aluminium silicate is the predominant chemical constituent of kaolin. Reconstituted kaolin samples were found to be ideal in this study on the grounds that kaolin (a) has appropriate ranges of particle sizes (silt and clay fractions), $(b)$ is relatively less expensive than obtaining undisturbed soil samples from the field and $(c)$ tests can be consistently repeated with confidence.

\section{Soil properties}

British standard BS 1377-2:1990 (BSI, 1990a) was adopted to determine the index properties such as $L_{\mathrm{L}}$ by using the Casagrande method as well as plastic limit $\left(P_{\mathrm{L}}\right)$ and particle size distribution. Both sieve and hydrometer analyses were carried out to determine the percentages of sand, silt and clay.

The particle size distribution of kaolin samples based on the sieve and hydrometer analyses is shown in Figure 1. The clay contents $(<2 \mu \mathrm{m})$ of KM20, KM25, KM35 and KM55 were found to be
$10 \cdot 95,19 \cdot 50,21 \cdot 12$ and $24 \cdot 38 \%$, respectively, while the silt contents $(2-60 \mu \mathrm{m})$ of KM20, KM25, KM35 and KM55 were $84 \cdot 61,79 \cdot 62,78 \cdot 00$ and $74 \cdot 75 \%$, respectively.

The $L_{\mathrm{L}}, P_{\mathrm{L}}$ and $P_{\mathrm{I}}$ of the kaolin samples are summarised in Table 1 . They are found to be directly proportional to the clay contents of the kaolin samples as shown in Figure 2. The reconstituted kaolin samples are classified as high-plasticity silt (MH) in accordance with ASTM D 2487 (ASTM, 2000).

The activity $\left(A_{\mathrm{c}}\right)$ of fine-grained soils, the ratio of $P_{\mathrm{I}}$ to the percentage clay content, is the amount of water that is attracted to the surfaces of the soil particles. The amount of water attracted is largely influenced by the amount of clay that is present in the soil (Lambe and Whitman, 1969; Skempton, 1953). Skempton (1953) stated that $A_{\mathrm{c}}$ provides a convenient value for assessing the particular minerals found in clay. In other words, before X-ray diffraction tests are done on the samples, soils with different minerals, such as kaolin, can be differentiated by their respective $A_{\mathrm{c}}$ values since different minerals are characterised by their unique $A_{\mathrm{c}}$ values. Table 1 shows that the $A_{\mathrm{c}}$ of the reconstituted kaolin samples are $0.66,0.55,0.77$ and 0.62 for KM20, KM25, KM35 and KM55, respectively, which are considered reasonable as they are generally close to the $A_{\mathrm{c}}$ value given by Skempton (1953) $\left(A_{\mathrm{c}}=0 \cdot 46\right)$ and Ferreira and Bica $(2006)\left(A_{\mathrm{c}}=0 \cdot 66\right)$.

\section{Testing procedures}

The one-dimensional (1D) consolidation (oedometer) tests were also conducted in accordance with BS 1377-5:1990 (BSI, 1990b) and ASTM D 2435 (ASTM, 2011) to examine the compressibility characteristics. Consolidated isotropic undrained (CIU) triaxial tests were performed based on BS 1377-8:1990 (BSI, 1990c) and Head (1998) in order to obtain the shear strength characteristics.

Strips of filter paper were attached on the sides of the specimens for radial drainage as per specifications by Head (1998) so as to accelerate the consolidation during the consolidation phase. The specimens were saturated by applying back pressures until Skempton's pore pressure parameter $(B)$ value of at least 0.98 was achieved. The CIU tests were carried out at different initial effective

Table 2. Summary of the conducted tests

\begin{tabular}{|c|c|c|c|c|}
\hline Test & KM20 & KM25 & КM35 & KM55 \\
\hline $\begin{array}{l}L_{\mathrm{L}}, P_{\mathrm{L}} \text { and } P_{\mathrm{I}} \\
\text { Sieve and hydrometer } \\
\text { Oedometer } \\
\mathrm{CIU}\end{array}$ & $\begin{array}{l}2 \\
2 \\
2 \\
2\end{array}$ & $\begin{array}{l}2 \\
2 \\
2 \\
2\end{array}$ & $\begin{array}{l}2 \\
2 \\
2 \\
2\end{array}$ & $\begin{array}{l}2 \\
1 \\
2 \\
2\end{array}$ \\
\hline \multicolumn{5}{|c|}{ Effective confining pressure, $p_{c}^{\prime}: k P a$} \\
\hline $\begin{array}{l}100 \\
150 \\
200 \\
250 \\
300 \\
400\end{array}$ & $\begin{array}{l}\text { KM20-100 } \\
\text { KM20-150 } \\
\text { KM20-200 } \\
\text { KM20-250 } \\
\text { KM20-300 } \\
\text { KM20-400 }\end{array}$ & $\begin{array}{l}\text { KM25-100 } \\
\text { KM25-150 } \\
\text { KM25-200 } \\
\text { KM25-250 } \\
\text { KM25-300 } \\
\text { KM25-400 }\end{array}$ & $\begin{array}{l}\text { KM35-100 } \\
\text { KM35-150 } \\
\text { KM35-200 } \\
\text { KM35-250 } \\
\text { KM35-300 } \\
\text { KM35-400 }\end{array}$ & $\begin{array}{l}\text { KM55-100 } \\
\text { KM55-150 } \\
\text { KM55-200 } \\
\text { KM55-250 } \\
\text { KM55-300 } \\
\text { KM55-400 }\end{array}$ \\
\hline
\end{tabular}


confining pressures of $100,150,200,250,300$ and $400 \mathrm{kPa}$. As the time taken for consolidation was shorter than $2 \mathrm{~h}$ for all specimens, a minimum of $2 \mathrm{~h}$ was considered in order to calculate the required shearing rates as suggested by Head (1998). As such, a shearing rate of $0.07 \mathrm{~mm} / \mathrm{min}$ was adopted. A similar shearing rate was also reported by Pillai et al. (2011) for tests on kaolin.

During the consolidation phase of the triaxial test, the volume change of the sample was continuously monitored with time. The post-consolidation dimensions were determined using equations 6.3(b) and 6.3(c) of BS 1377-8:1990 (BSI, 1990c). Once the consolidation was over, the sample was sheared under undrained conditions. The axial load, axial deformation and the pore pressures were recorded using a load cell, a displacement transducer and a pore pressure transducer, respectively. The tests were continued until axial strain of $20 \%$ was reached. The corrected length was used for computing the strains during the shearing stage.

CIU tests at six different initial effective confining pressures of $100,150,200,250,300$ and $400 \mathrm{kPa}$ were carried out for each type of kaolin sample with varying clay-silt contents (KM20, KM25, KM35 and KM55). Therefore, a total of 24 CIU tests were performed. The samples were labelled based on the type of kaolin and the confining pressure in the triaxial test. For example, KM20-100 means $100 \mathrm{kPa}$ confining pressure was applied on the sample KM20. The conducted tests are summarised in Table 2.

\section{Sample preparation}

\section{Reconstituted and undisturbed samples}

Burland (1990) demonstrated that the reconstituted clay should be mixed at higher water contents from 1.00 to 1.50 times its liquid limit $\left(L_{\mathrm{L}}\right)$ and preferably consolidated one-dimensionally to obtain the intrinsic properties of the soils. As there is no proper guideline for reconstituting kaolin silt, the mixing ratio as proposed by Burland (1990) has been adopted. A comparative mixing ratio was likewise embraced in the work of Pillai et al. (2011) for kaolin to prepare normally consolidated reconstituted samples.

In a different work by Hyodo et al. (1994), triaxial compression and extension tests were conducted on both normally consolidated undisturbed and reconstituted marine clays with a liquid limit of $124 \cdot 2 \%$, a plastic limit of $51 \cdot 4 \%$ and a plasticity index of $72 \cdot 8 \%$. The monotonic axial load was applied at an axial strain rate of $0 \cdot 1 \% / \mathrm{min}$. The test outcomes demonstrated that undisturbed and reconstituted samples behaved similarly in terms of deviator stresses and stress paths. Hyodo et al. (1994) added that the ageing effects such as chemical bonding or secondary compression for undisturbed samples were eliminated during the application of effective confining stress to the normally consolidated state during the consolidation stage. Therefore, the work of Hyodo et al. (1994) guaranteed that the behaviour of normally consolidated undisturbed samples can be decently depicted by reconstituted samples.

\section{Sample preparation}

The use of reconstituted kaolin samples prepared by consolidation of the soil-water mixture in the form of slurry state is a common approach in the laboratory testing of soils (Pillai et al., 2011; Wang and Luna, 2012). Firstly, the kaolin powder was mixed with distilled water at a water content of 1.50 times its liquid limit. The water-soil mixture was mixed thoroughly in an automatic soil mixer to form the slurry. For triaxial tests, $38 \mathrm{~mm}$ dia. samples were used. The slurry was directly poured into the $38 \mathrm{~mm}$ dia. sampling tube after applying silicone grease on the inner surfaces of the tubes to reduce side friction. Subsequently, the sample was gradually loaded to a vertical consolidation pressure of $100 \mathrm{kPa}$. The vertical consolidation pressure was achieved by the application of a dead weight of $11.5 \mathrm{~kg}$ on the sample through a guide rod.

After the consolidation stage, the kaolin samples were extruded using a universal extruder. The reconstituted kaolin samples were then trimmed to $38 \mathrm{~mm}$ diameter and $76 \mathrm{~mm}$ height.

For the 1D consolidation tests, the slurry was carefully poured into a $60 \mathrm{~mm}$ dia. and $20 \mathrm{~mm}$ high $1 \mathrm{D}$ consolidation ring along with the collar so that the thickness of the sample was $30 \mathrm{~mm}$. The slurry was initially consolidated to a consolidation pressure of $6.25 \mathrm{kPa}$. Once the consolidation under $6.25 \mathrm{kPa}$ was complete, the sample was carefully trimmed to a thickness of $20 \mathrm{~mm}$. The sample was then subjected to a 1D consolidation test with a load increment ratio of $1 \cdot 0$.

\section{Results and discussions}

\section{CIU tests}

Figures 3(a), 3(b) and 3(c) show the stress-strain behaviour, stress paths and pore pressure-strain behaviour of the reconstituted kaolin samples, respectively. For clarity, separate plots of these three parameters for the KM20, KM25, KM35 and KM55 samples can be found in Figures 4, 5, 6 and 7, respectively.

When the clay contents decreased (from KM55 to KM20), the deviator stresses at failure $\left(q_{\mathrm{f}}\right)$ increased as shown in Figure 3(a). The mean effective normal stress $\left(p^{\prime}\right)$ and deviator stress $(q)$ can be expressed as Equations 1 and 2a. Equation 2a can then be written in incremental form as shown in Equation $2 b$. For the CIU tests, the change in the total confining pressure $\left(\Delta \sigma_{3}\right)$ equals zero. Hence, Equation $2 \mathrm{~b}$ can be rewritten as Equations $2 \mathrm{c}$ and $2 \mathrm{~d}$ as the changes in deviator stress $(\Delta q)$ are defined as negative and positive for strain softening and hardening, respectively.

From Equations $2 \mathrm{c}$ and $2 \mathrm{~d}$, it is obvious that samples are expected to exhibit strain softening only if $(a)$ the change in the total vertical stress $\left(\Delta \sigma_{1}\right)$ or $(b)$ the summation of the changes in the effective vertical stress $\left(\Delta \sigma_{1}^{\prime}\right)$ and excess pore water pressure $(\Delta u)$ is negative. In other words, the kaolin samples will strain soften, due to the negative value of $\Delta u$ (dilation) and/or negative value of $\Delta \sigma_{1}^{\prime}$ (axial unloading). 
Behaviour of MH silts with varying

plasticity indices

Wong, Ong and Robinson

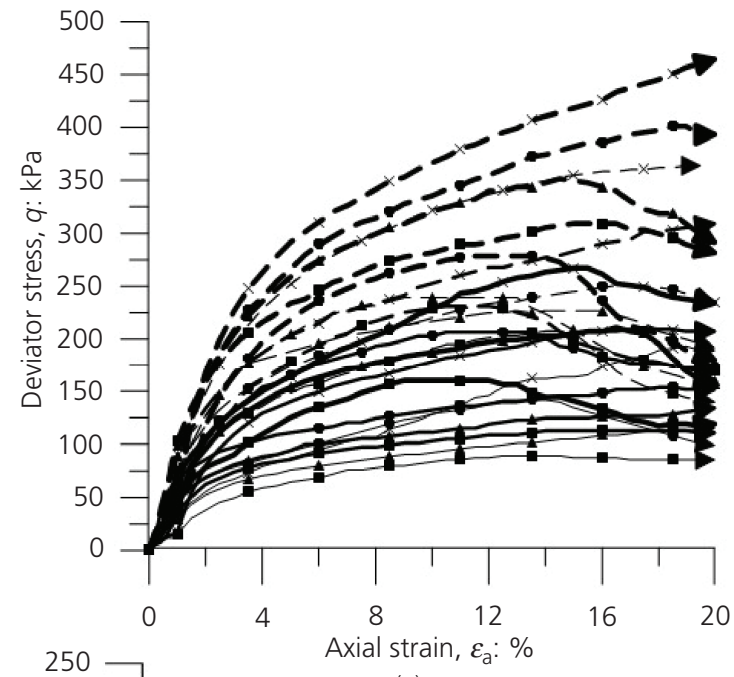

(a)

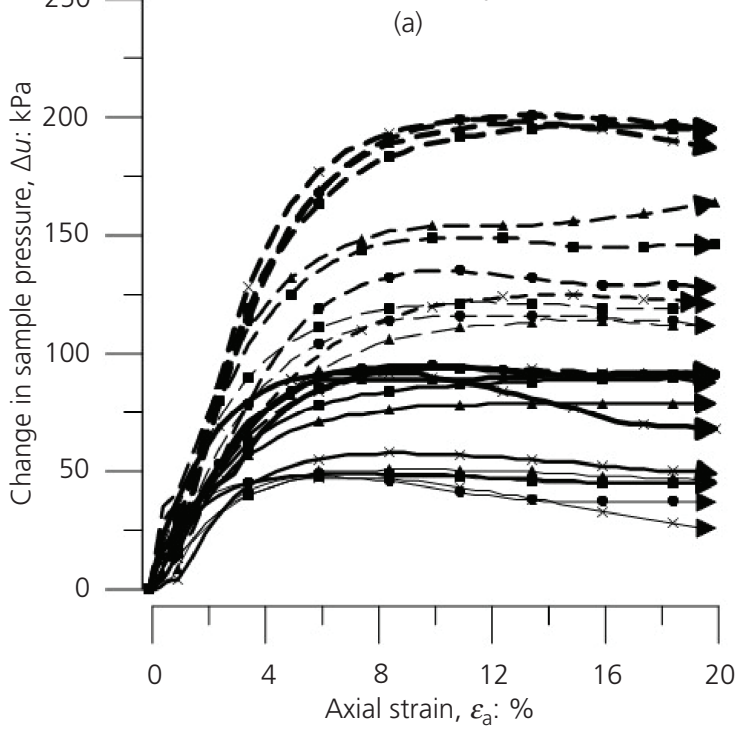

(c)

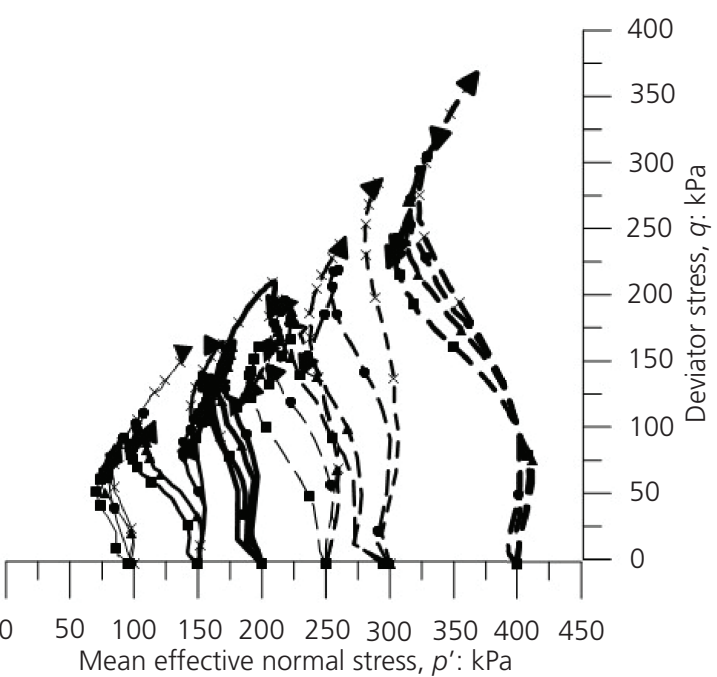

(b)

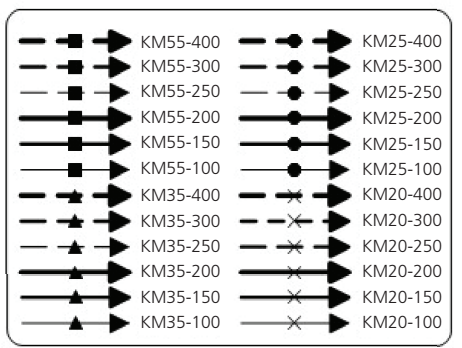

Figure 3. (a) Stress-strain, (b) stress paths and (c) pore pressure-strain behaviours of kaolinite samples subjected to CIU tests

Similarly, the kaolin samples will exhibit strain hardening if (a) the change in $\Delta \sigma_{1}$ or $(b)$ the summation of $\Delta \sigma_{1}^{\prime}$ and excess pore water pressure $(\Delta u)$ is positive. The kaolin samples will strain harden due to the positive values in $\Delta u$ (contraction) and/or positive value in $\Delta \sigma_{1}^{\prime}$ (compression)

1. $p^{\prime}=\frac{\sigma_{1}^{\prime}+2 \sigma_{3}^{\prime}}{3}$

2a. $\quad q=\sigma_{1}^{\prime}-\sigma_{3}^{\prime}$

2b. $\Delta q=\Delta \sigma_{1}^{\prime}-\Delta \sigma_{3}^{\prime}=\Delta \sigma_{1}-\Delta \sigma_{3}$
For softening

2c. $\Delta q=\Delta \sigma_{1}=\Delta \sigma_{1}^{\prime}+\Delta u<0$

For hardening

2d. $\Delta q=\Delta \sigma_{1}=\Delta \sigma_{1}^{\prime}+\Delta u>0$

The effective stress paths in Figure 3(b) were plotted in the Cambridge stress space with Equation 1 in the abscissa and Equation $2 \mathrm{a}$ in the ordinate. A similar approach was also adopted by Wang and Luna (2012) to understand the stress paths of silts. The effective stress paths of KM20 and KM25 with the lower $P_{\mathrm{I}}$ 
Behaviour of $\mathrm{MH}$ silts with varying

plasticity indices

Wong, Ong and Robinson

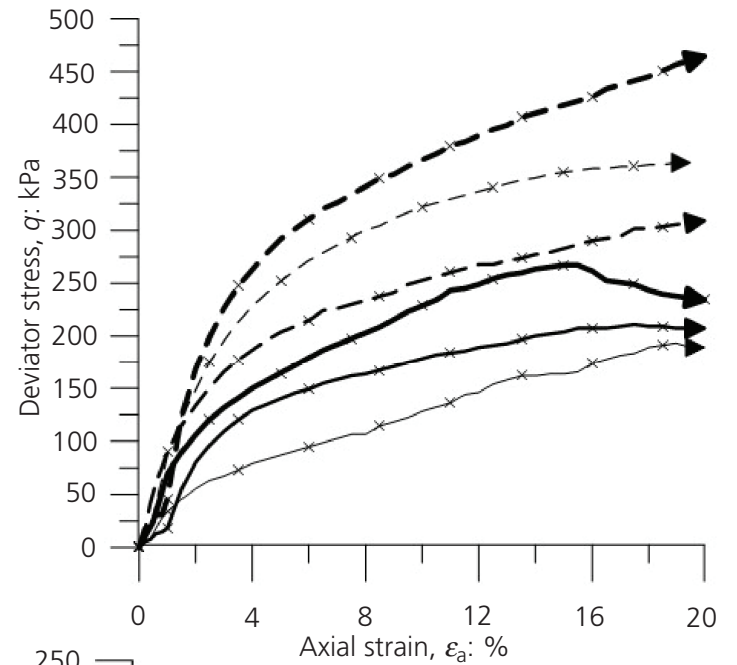

(a)

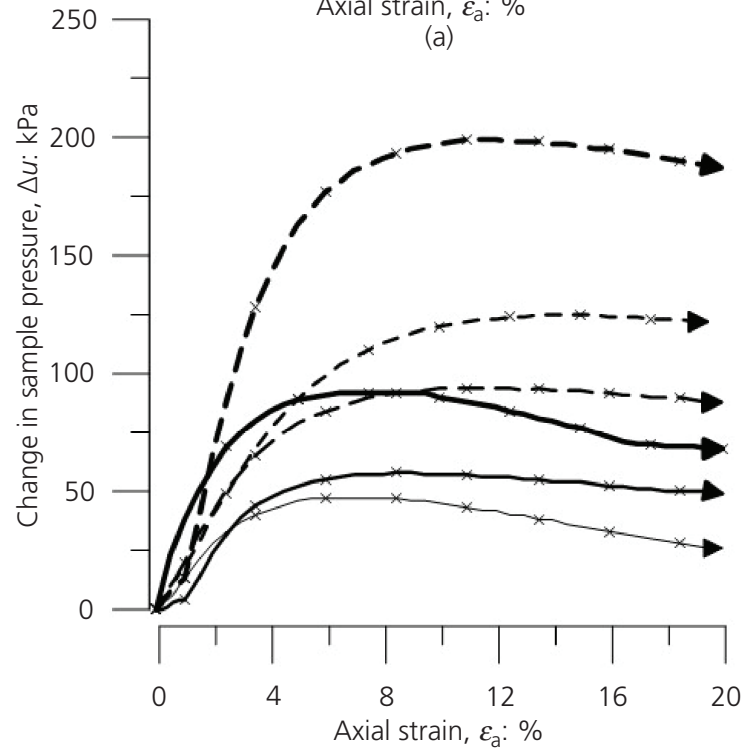

(c)

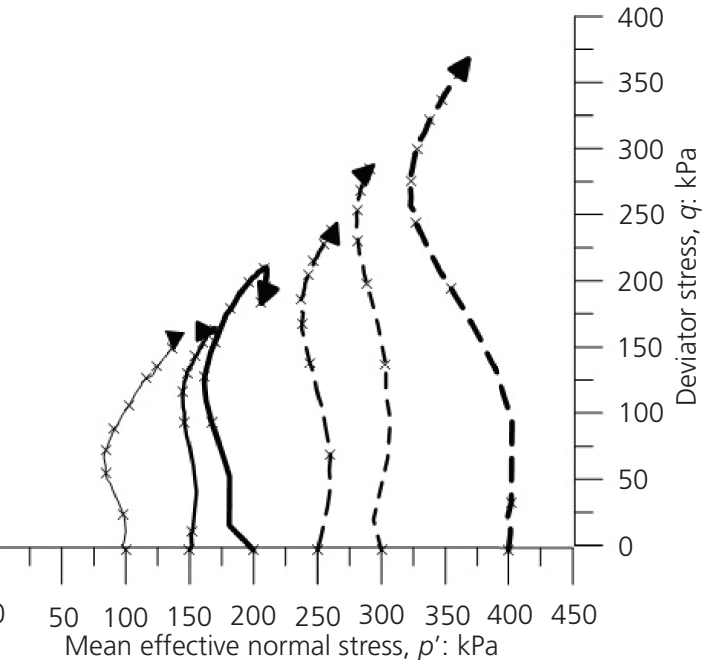

(b)

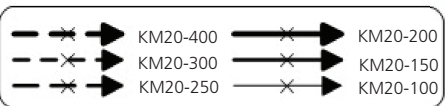

Figure 4. (a) Stress-strain, (b) stress paths and (c) pore pressure-strain behaviours of KM20 kaolin samples subjected to CIU tests

values of $7 \%$ and $11 \%$, respectively, curved away from the origin of mean effective normal stress $\left(p^{\prime}\right)$, but the effective stress paths of KM35 and KM55 with higher $P_{\mathrm{I}}$ values of 16 and $15 \%$, respectively, curved towards the origin of $p^{\prime}$.

Figure 3(c) shows the pore pressure behaviour of the kaolin samples. Table 3 summarises the changes in effective vertical stresses and pore pressures. As shown in Figure 3(a), KM20 exhibited strain softening at $\sigma_{3}^{\prime}$ values of 100,150 and $200 \mathrm{kPa}$ due to the development of negative values of $\Delta u$ (dilation). This is because of having negative values in both $\Delta u$ and $\Delta \sigma_{1}^{\prime}$ as well as the summation of $\Delta u$ and $\Delta \sigma_{1}^{\prime}$ being similarly negative, resulting in the change in deviator stress $(\Delta q)$ also being a negative value (see Equation 2c). Theoretically, KM20 is expected to exhibit strain softening at the aforementioned confining pressures, as observed in Figure 3(a) or Figure 4 for better clarity. However, on the contrary, with KM20 tested under confining pressures $\sigma_{3}^{\prime}$ of
250,300 and $400 \mathrm{kPa}$, the values of $\Delta \sigma_{1}^{\prime}$ become positive (compression). As such, KM20 is expected to show strain hardening with positive $\Delta q$ values as per Equation $2 \mathrm{~d}$ and as observed in Figure 3(a) or Figure 4 for better clarity.

For KM25, dilation can be observed when the samples are tested with confining pressures of $\sigma_{3}^{\prime}$ of $100,200,250,300$ and $400 \mathrm{kPa}$, except $150 \mathrm{kPa}$, with no change in $\Delta u . \Delta \sigma_{1}^{\prime}$ at all effective confining pressures are negative values (denoting axial unloading behaviour), except $\sigma_{3}^{\prime}=100 \mathrm{kPa}$, which showed a small positive value (slight compression). Hence, with Equation 2c, KM25 is expected to show strain softening behaviour at all the tested $\sigma_{3}^{\prime}$ values due to the summation of $\Delta u$ and $\Delta \sigma_{1}^{\prime}$ or $\Delta q$ being all negative values. By comparing with Figure 5 for better clarity, this observation holds true.

For KM35, the samples have shown slight dilation at $\sigma_{3}^{\prime}$ of 100 and $400 \mathrm{kPa}$, and no dilation or slight contraction at $\sigma_{3}^{\prime}$ of 150 , 


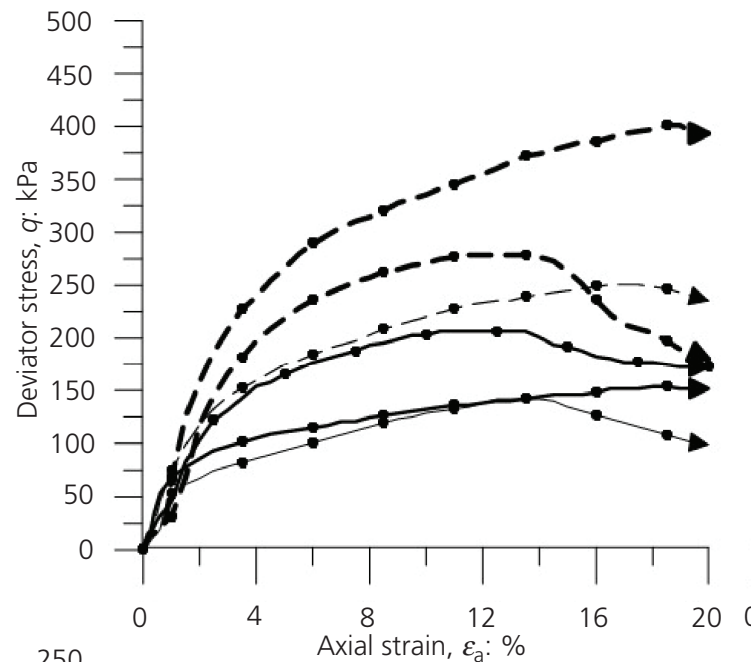

(a)

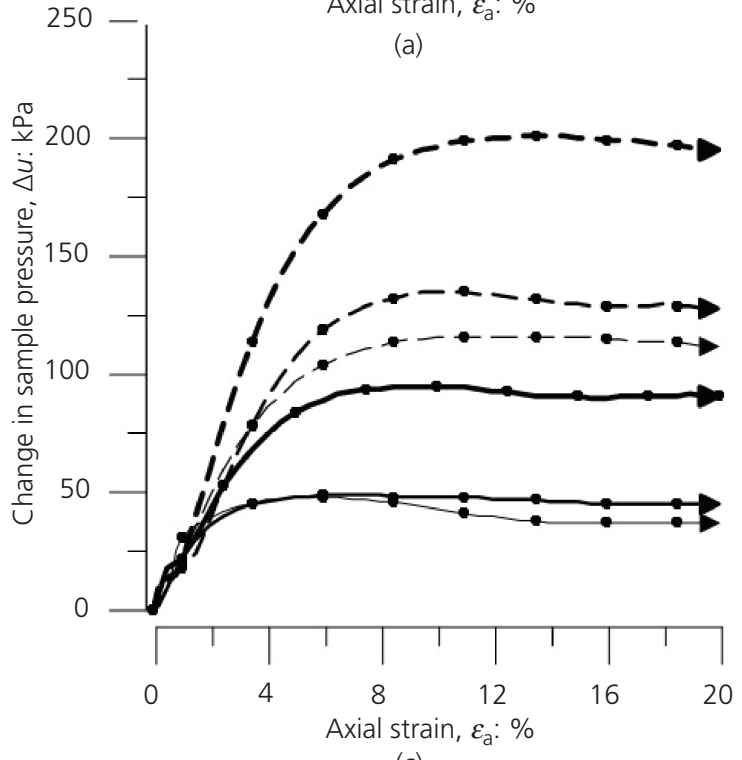

(c)

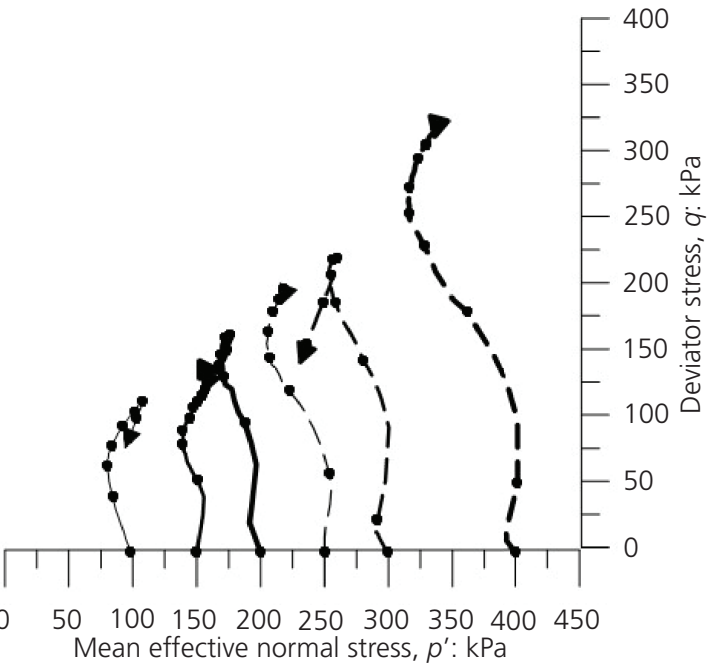

(b)

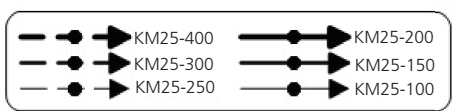

Figure 5. (a) Stress-strain, (b) stress paths and (c) pore pressure-strain behaviours of KM25 kaolin samples subjected to CIU tests

200, 250 and $300 \mathrm{kPa}$ as shown in Table 3. For KM55, the samples show slight dilation at $\sigma_{3}^{\prime}$ of 100, 200, 250, 300 and $400 \mathrm{kPa}$; while at $150 \mathrm{kPa}$ it shows no dilation. It can be seen that the strain softening and hardening of KM35 and KM55 samples are governed by their more significant and dominant values of $\Delta \sigma_{1}^{\prime}$.

For example, KM35 has shown strain hardening at $\sigma_{3}^{\prime}$ of 100 and $150 \mathrm{kPa}$ due to the positive values of $\Delta \sigma_{1}^{\prime}$ (compression) greater than $\Delta u$; hence, the samples have shown positive values in $\Delta q$ based on Equation 2d. For other $\sigma_{3}^{\prime}$ values of KM35 and all $\sigma_{3}^{\prime}$ values of KM55, the negative values of $\Delta \sigma_{1}^{\prime}$ (axial unloading) are greater than $\Delta u$, so the samples have shown negative values (strain softening) in $\Delta q$ of Equation 2c. By observing Figure 3(a), or for better clarity Figures 6 and 7, the behaviours of strain softening and strain hardening are very obvious.
Ishihara et al. (1975) defined the phase transformation point as the point at which the stress path turns its direction in $p^{\prime}-q$ space. They also observed that for cyclic triaxial tests, it is necessary for a sample to go at least once through this critical value in order to be taken to a completely liquefied state. In this sense, the phase transformation point may be considered as a threshold at which the behaviour of sand as a solid is lost and transformed into that of a liquefied state.

As shown in Figures 4(b), 5(b), 6(b) and 7(b), all samples exhibited the initial contraction before the phase transformation points. As shown in Table 3, all samples exhibit post-peak dilation except for KM25-150, KM35-150, KM35-200, KM35250 and KM55-150. Except for KM20-250, KM20-300, KM20400, KM35-100 and KM35-150, all the samples exhibited postpeak strain softening. 
Behaviour of $\mathrm{MH}$ silts with varying

plasticity indices

Wong, Ong and Robinson

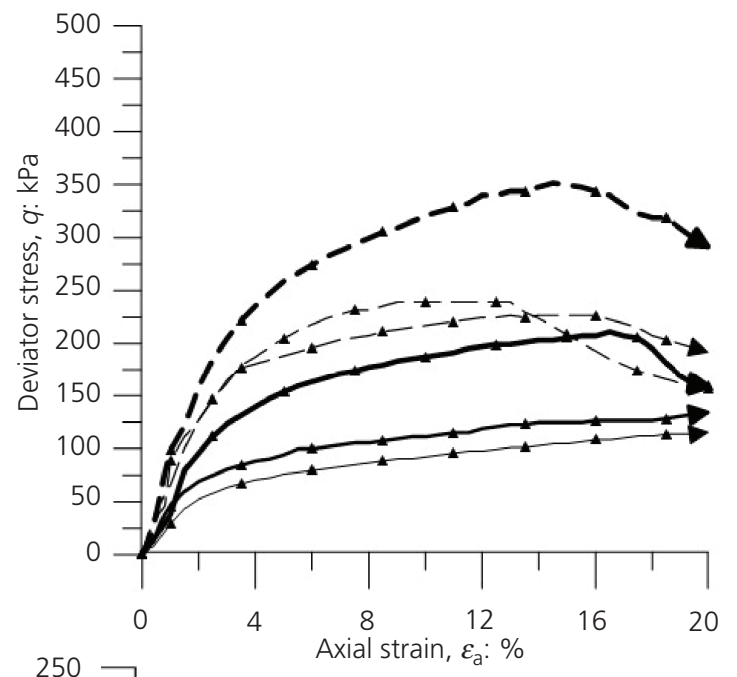

(a)

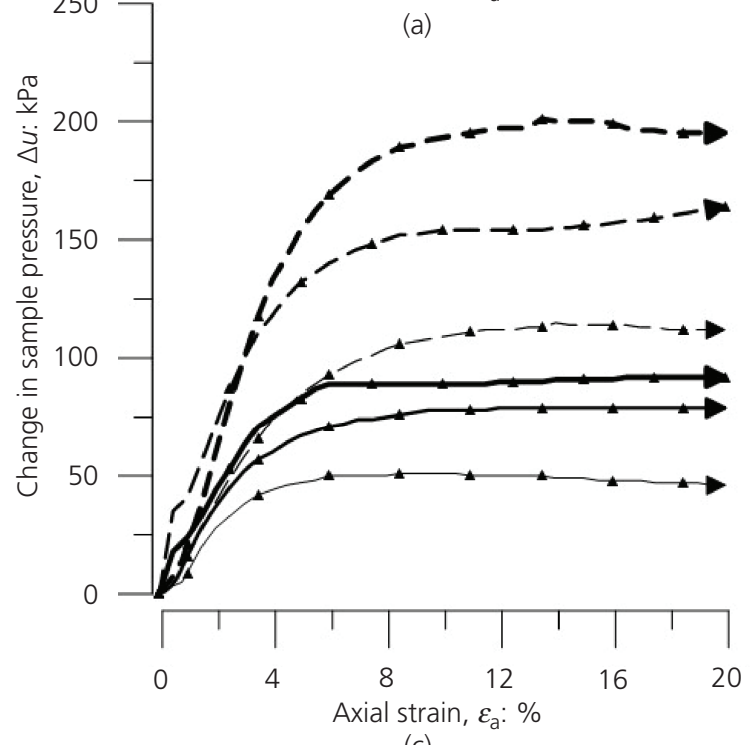

(c)

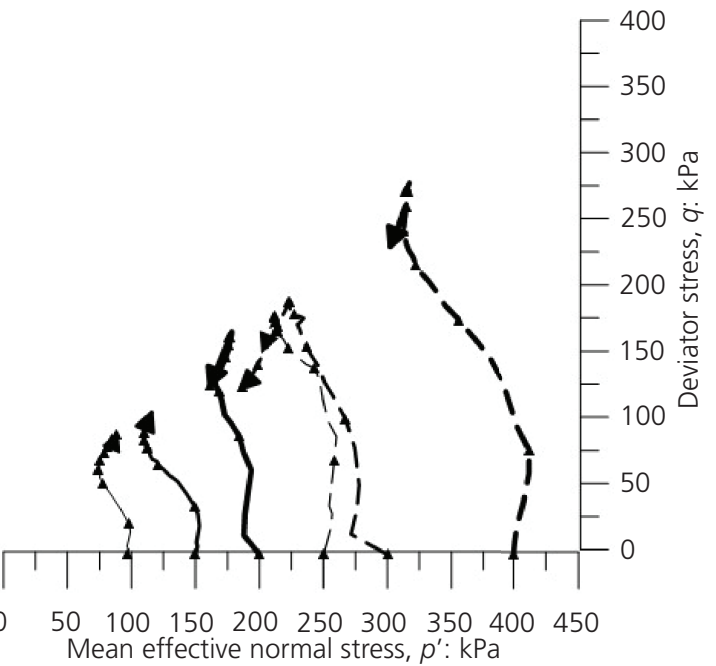

(b)

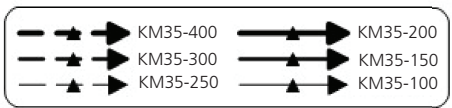

Figure 6. (a) Stress-strain, (b) stress paths and (c) pore pressure-strain behaviours of KM35 kaolin samples subjected to CIU tests

\section{Critical state}

The deviator stresses at failure $\left(q_{\mathrm{f}}\right)$ can be identified when either of the following conditions are achieved: $(a)$ maximum principal stress ratio $\left(\sigma_{1}^{\prime} / \sigma_{3}^{\prime}\right)$ and $(b)$ 'critical-state' condition - that is, constant deviator stress and pore pressure. The corresponding values of strain and pore pressure are axial strain at failure $\left(\varepsilon_{\mathrm{f}}\right)$ and pore pressure at failure $\left(u_{\mathrm{f}}\right)$, respectively (Head, 1998). The work of Wang and Luna (2012) showed that the criterion of maximum principal stress ratio always gives a consistent estimation of the effective angle of shearing resistance. Hence, in the present study, the maximum principal stress ratio method has been used to identify $q_{\mathrm{f}}$.

The outcome of projecting the effective stress paths in Figure 3(b) onto the semilogarithmic plot of $v-\ln p^{\prime}$ is shown in Figure 8. As drainage was not allowed during the shearing stage of the sample, the effective stress paths in $v-\ln p^{\prime}$ were expected only to move horizontally since undrained shearing occurred at constant specific volume. It is observed that the CSLs and the NCLs are not parallel as shown in Figure 8 for the kaolin with lower clay contents (KM20 and KM25) due to the $P_{\mathrm{I}}$ values of KM20 and KM25 being lower at 7 and $11 \%$, respectively, compared to other samples, which have $P_{\mathrm{I}}$ values greater than $13 \%\left(\mathrm{KM} 35\left(P_{\mathrm{I}}=16 \%\right)\right.$ and $\left.\operatorname{KM} 55\left(P_{\mathrm{I}}=15 \%\right)\right)$. Therefore, it is defined that KM20 and KM25 behave as sand-like materials. A similar observation of non-parallel CSL and NCL curves was also reported by Wang and Luna (2012) in their study of triaxial compression test on the MRV silt with $P_{\mathrm{I}}$ of $6 \%$. Furthermore, it is interesting to observe that as the $P_{\mathrm{I}}$ values of the kaolin samples increased starting from KM20 $\left(P_{\mathrm{I}}=7 \%\right)$ and $\operatorname{KM} 25\left(P_{\mathrm{I}}=11 \%\right)$ to $\operatorname{KM} 35\left(P_{\mathrm{I}}=16 \%\right)$ and $\operatorname{KM} 55\left(P_{\mathrm{I}}=15 \%\right)$, the gradients of the respective CSLs seem to be getting more and more parallel to the gradients of their corresponding NCLs, indicating that the clay-like behaviour starts to be more prominent 


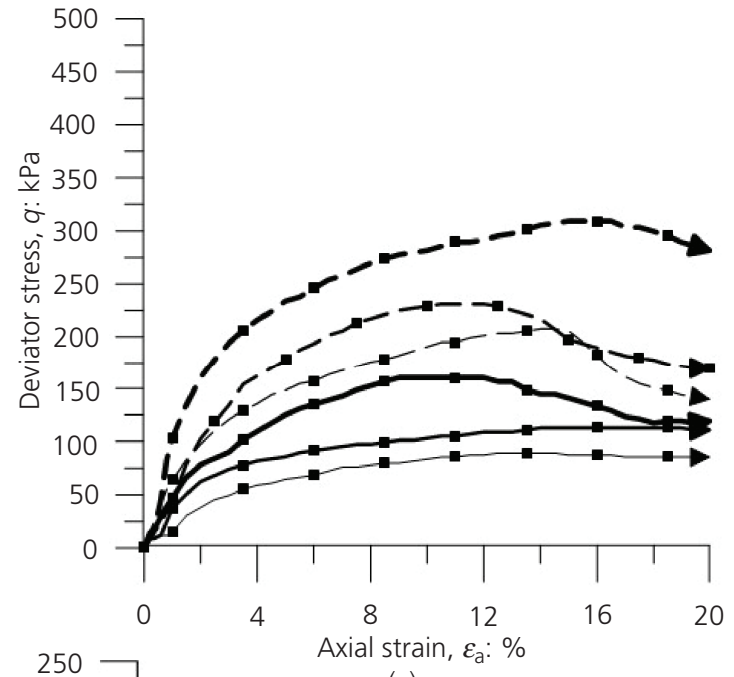

(a)

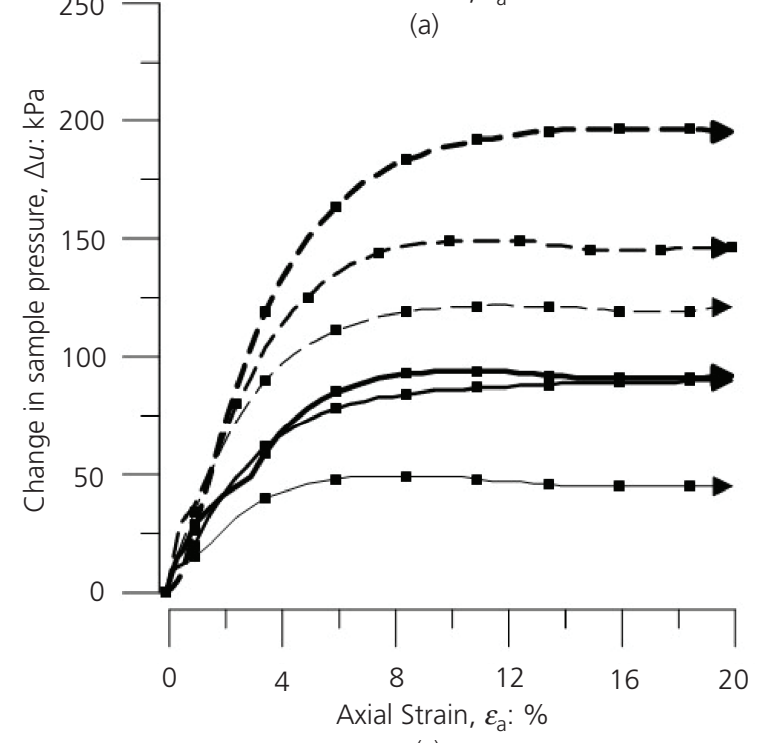

(c)

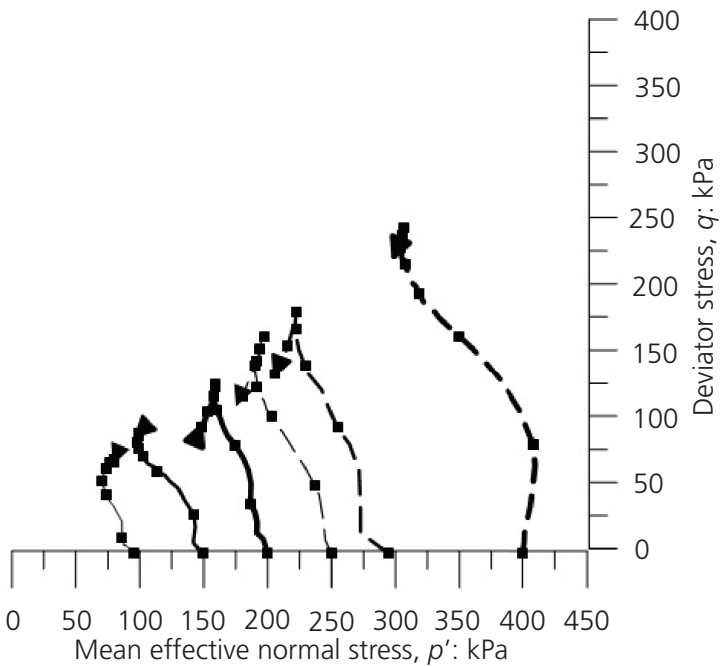

(b)

Figure 7. (a) Stress-strain, (b) stress paths and (c) pore pressure-strain behaviours of KM55 kaolin samples subjected to CIU tests

progressively. Therefore, for KM20 and KM25 with the relatively lesser $P_{\mathrm{I}}$ values, the non-parallel NCLs and CSLs seem to suggest that the sample demonstrated a more dominant sand-like behaviour instead, when compared to those $\mathrm{KM}$ samples with greater $P_{\mathrm{I}}$ values.

As shown in Figure 9 for better clarity, the normalised deviator stress of KM20 and KM25 cannot be effectively bound by the effective consolidation pressures $\left(p_{\mathrm{c}}^{\prime}\right)$ into a narrower single band, particularly at $100 \mathrm{kPa}$ for $p_{\mathrm{c}}^{\prime}$, which indicates that they are not clay-like materials. Comparatively, KM35 and KM55 can be better normalised by $p_{\mathrm{c}}^{\prime}$ into a single band and have shown a unique behaviour as clay-like materials.

Based on this important observation, since KM35 and KM55 have higher $P_{\mathrm{I}}$ values and their NCLs and CSLs are much more parallel (evident in Figure 8), it is thus postulated that KM35 and KM55 demonstrate clay-like behaviours. In view of this, a $P_{\mathrm{I}}$ value of equal to or greater than $13 \%$ can be postulated as the boundary when claylike behaviour types of soils would start to dominate. Similar results were also reported by Wang and Luna (2012) and Boulanger and Idriss (2006) in their works, which showed sand-like materials exhibiting non-parallel NCL and CSL behaviours.

Table 4 summarises the results of the CIU tests performed on the reconstituted kaolin soils. Based on the mean effective normal stress at failure $\left(p_{\mathrm{f}}^{\prime}\right)$ and $q_{\mathrm{f}}$ from Table 4 , the CSLs of reconstituted kaolin soil samples are then determined, as shown in Figure 10. The slope of the CSL increased when the clay contents of the reconstituted kaolin soils reduced. The slope of the CSL is $M$, and the effective angle of shearing resistance friction $\left(\phi^{\prime}\right)$ can be back-calculated using the following equation. 
Table 3. Changes in effective vertical stresses and pore pressures

\begin{tabular}{|c|c|c|c|c|}
\hline Sample & Axial strains: \% & $\Delta \sigma_{1}^{\prime}$ & $\Delta u$ & $\Delta \sigma_{1}^{\prime}+\Delta u$ \\
\hline KM20-100 & $19 \cdot 0-20 \cdot 0$ & -2.95 & $-3.95(d)$ & $-6 \cdot 89(s)$ \\
\hline KM20-150 & $18 \cdot 0-20 \cdot 0$ & $-1 \cdot 82$ & $-1.00(d)$ & $-2 \cdot 82(s)$ \\
\hline KM20-200 & $15 \cdot 5-20 \cdot 0$ & $-22 \cdot 45$ & $-5 \cdot 00(d)$ & $-27 \cdot 45(s)$ \\
\hline KM20-250 & $12 \cdot 5-20 \cdot 0$ & $41 \cdot 49$ & $-6 \cdot 00(d)$ & $35.49(h)$ \\
\hline KM20-300 & $16 \cdot 0-20 \cdot 0$ & $7 \cdot 43$ & $-2 \cdot 00(d)$ & $5.43(h)$ \\
\hline KM20-400 & $12 \cdot 0-20 \cdot 0$ & $74 \cdot 82$ & $-12 \cdot 00(d)$ & $62 \cdot 82(h)$ \\
\hline KM25-100 & $7 \cdot 0-20 \cdot 0$ & 0.67 & $-10 \cdot 00(d)$ & $-9 \cdot 33(\mathrm{~s})$ \\
\hline KM25-150 & $18 \cdot 5-20 \cdot 0$ & -1.95 & $0.00(-)$ & $-1.95(\mathrm{~s})$ \\
\hline KM25-200 & $11 \cdot 0-20 \cdot 0$ & $-30 \cdot 82$ & $-3 \cdot 00(d)$ & $-33.82(\mathrm{~s})$ \\
\hline KM25-250 & $17 \cdot 5-20 \cdot 0$ & $-15 \cdot 19$ & $-2 \cdot 00(d)$ & $-17 \cdot 19(\mathrm{~s})$ \\
\hline KM25-300 & $12 \cdot 0-20 \cdot 0$ & -93.66 & $-5 \cdot 00(d)$ & $-98 \cdot 66(s)$ \\
\hline KM25-400 & $19 \cdot 0-20 \cdot 0$ & $-7 \cdot 71$ & $-1.00(d)$ & $-8.71(s)$ \\
\hline KM35-100 & $10 \cdot 5-20 \cdot 0$ & $23 \cdot 86$ & $-4.00(d)$ & $19 \cdot 86(h)$ \\
\hline KM35-150 & $12 \cdot 5-20 \cdot 0$ & $13 \cdot 43$ & $0.00(-)$ & $13 \cdot 43(h)$ \\
\hline KM35-200 & $16 \cdot 5-20 \cdot 0$ & $-47 \cdot 85$ & $0.00(-)$ & $-47 \cdot 85(s)$ \\
\hline KM35-250 & $11 \cdot 5-20 \cdot 0$ & $-30 \cdot 75$ & $0.00(-)$ & $-30 \cdot 75(s)$ \\
\hline KM35-300 & $13 \cdot 0-20 \cdot 0$ & $-83 \cdot 37$ & $10 \cdot 00(-)$ & $-73 \cdot 37(s)$ \\
\hline KM35-400 & $14 \cdot 5-20 \cdot 0$ & $-59 \cdot 88$ & $-5 \cdot 00(d)$ & $-64 \cdot 88(s)$ \\
\hline KM55-100 & $12 \cdot 5-20 \cdot 0$ & $-2 \cdot 79$ & $-1.00(d)$ & $-3 \cdot 79(\mathrm{~s})$ \\
\hline KM55-150 & $19 \cdot 0-20 \cdot 0$ & -1.95 & $0.00(-)$ & $-1.95(s)$ \\
\hline KM55-200 & $12 \cdot 0-20 \cdot 0$ & $-36 \cdot 16$ & $-1.00(d)$ & $-37 \cdot 16(s)$ \\
\hline KM55-250 & $12 \cdot 0-20 \cdot 0$ & $-61 \cdot 47$ & $-1.00(d)$ & $-62 \cdot 47(\mathrm{~s})$ \\
\hline KM55-300 & $12 \cdot 0-20 \cdot 0$ & $-56 \cdot 27$ & $-3 \cdot 00(d)$ & $-59 \cdot 27(s)$ \\
\hline KM55-400 & $16 \cdot 5-20 \cdot 0$ & $-27 \cdot 77$ & $-1 \cdot 00(d)$ & $-28.77(s)$ \\
\hline
\end{tabular}

d, dilation; c, contraction; s, softening; h, hardening

3. $\sin \phi^{\prime}=\frac{6 M}{6+M}$

A similar approach was also used by Wang and Luna (2012) to find the $\phi^{\prime}$ value. The $M$ and $\phi^{\prime}$ values of the kaolin soils are summarised in Table 4.

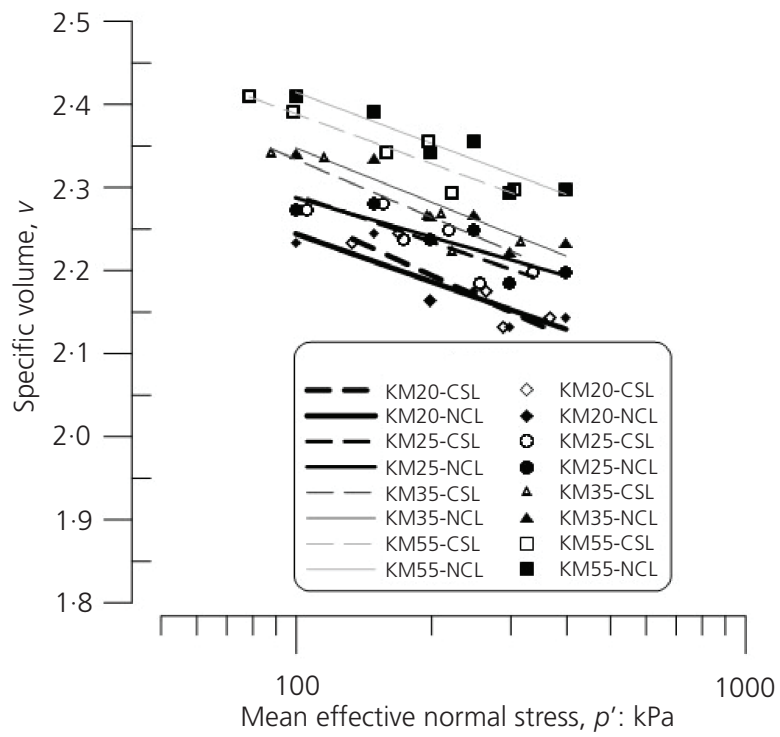

Figure 8. CSLS and isotropically NCLS of kaolin samples derived from CIU tests
The relationship between the clay contents and effective angles of shearing resistance is indirectly proportional as shown in Figure 11. The correlation between clay contents $\left(C_{\mathrm{L}} \%\right)$ and effective angle of shearing resistance $\left(\phi^{\prime}\right)$ for the kaolin is

4. $\phi^{\prime}=34.6422-0.3323 \times C_{\mathrm{L}} \%$

with coefficient of determination $\left(R^{2}\right)$ equal to $0 \cdot 931$. Similarly, Nocilla and Coop (2008) conducted CIU triaxial tests on alluvial sediments from the floodplain of Po River in Italy with $C_{\mathrm{L}} \%$ ranging from 16 to $25 \%$ and $P_{\mathrm{I}}$ ranging from 13 to $16 \%$. It was also found that the back-calculated $\phi^{\prime}$ showed a similar inverse correlation with $C_{\mathrm{L}} \%$. However, the observed scatters in their data set could be due to the presence and the variation in silt and sand contents.

\section{One-dimensional consolidation tests}

The compressibility of the reconstituted kaolin was determined using 1D consolidation tests. The semilogarithmic $e-\log \sigma_{\mathrm{v}}^{\prime}$ (effective vertical stress) relationships obtained from the 1D consolidation testing are plotted in Figure 12. The initial void ratio is directly proportional to the $L_{\mathrm{L}}$ of the soils. If the $L_{\mathrm{L}}$ is higher, the initial void ratio will also tend to be higher due to the higher water content present within the void of the samples. The results of the $1 \mathrm{D}$ consolidation tests are summarised in Table 5. Furthermore, the gradient of compression line $(\lambda)$ and the gradient of swelling line $(\kappa)$ show a directly proportional relationship with the $C_{\mathrm{L}} \%$ of the samples, as shown in Figure 13 . 

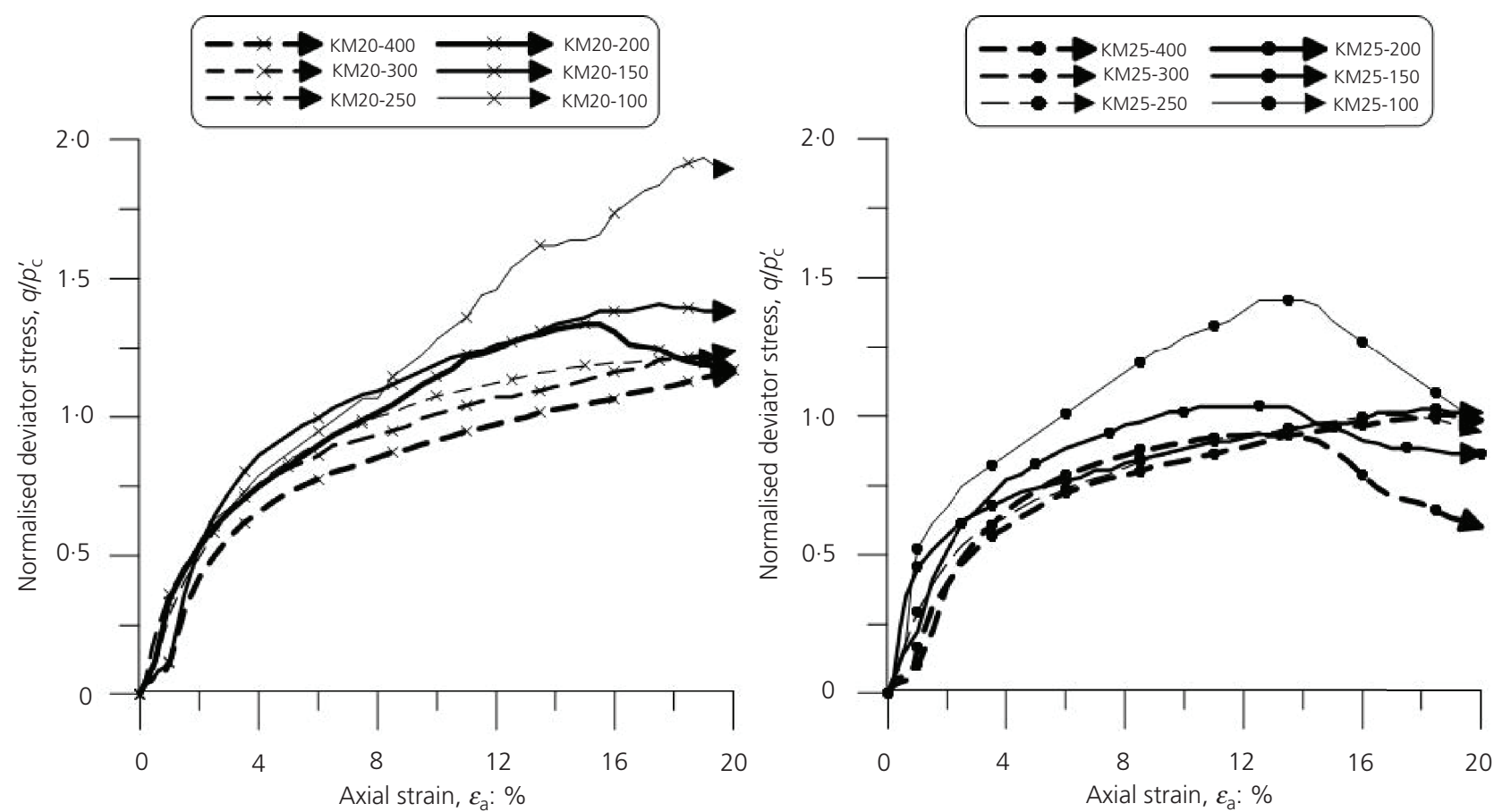

(a)

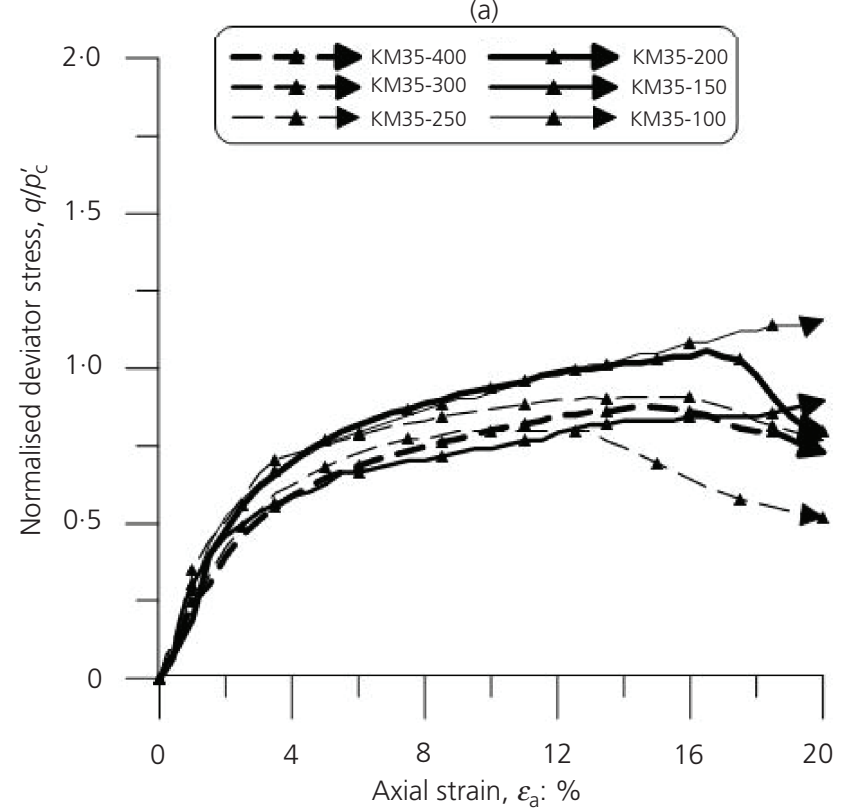

(c)

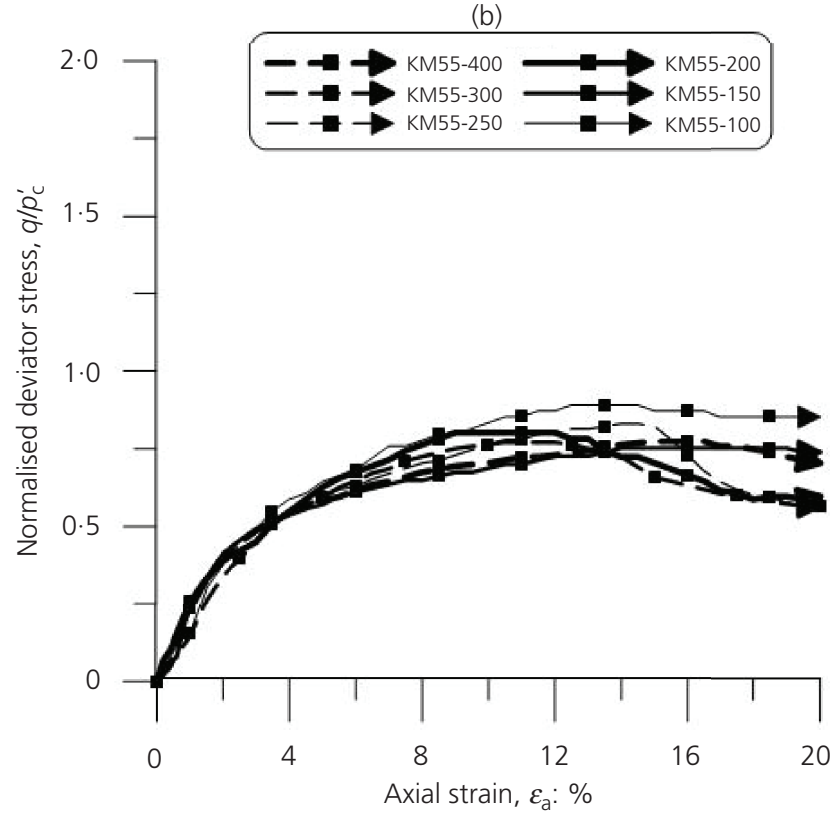

(d)

Figure 9. (a) Normalised deviator stress-strain plots for KM20; (b) normalised deviator stress-strain plots for KM25; (c) normalised deviator stress-strain plots for KM35; (d) normalised deviator stress-strain plots for KM55

\section{Gradient of compression lines of NCL and CSL from CIU tests}

The gradients of the compression lines of the reconstituted kaolins were back-calculated from the NCLs and CSLs of the CIU tests as shown in Figure 8. Both the gradients of the compression lines of NCLs and CSLs are directly proportional to the clay contents as shown in Table 6. Furthermore, the gradient of the compression lines of NCL $\left(\lambda_{\mathrm{NCL}}\right)$ converges to the gradient of the compression lines of CSL $\left(\lambda_{\mathrm{CSL}}\right)$ when the clay content of kaolin increases. This also indicates that the NCLs and CSLs of KM55 and KM35 are relatively more parallel than the NCLs and CSLs of KM20 and KM25. As shown in Figure 14 and Table 6, the ratios of the gradients of compression lines $\left(\lambda_{\mathrm{NCL}} / \lambda_{\mathrm{CSL}}\right)$ of KM20, KM25, KM35 and KM55 are 0.702, 0.806, 0.846 and 0.948, respectively. A value of $\lambda_{\mathrm{NCL}} / \lambda_{\mathrm{CSL}}$ closer to 1.000 indicates that the NCL and CSL are more parallel. The $R^{2}$ of the $\lambda_{\mathrm{NCL}} / \lambda_{\mathrm{CSL}}$ and 
Behaviour of $\mathrm{MH}$ silts with varying

plasticity indices

Wong, Ong and Robinson

Table 4. Results of CIU tests, slopes of CSLs and effective angles of shearing resistance

\begin{tabular}{|c|c|c|c|c|c|c|c|}
\hline Sample & $p_{c}^{\prime}: k P a$ & $p_{f}^{\prime}: k P a$ & $q_{f}: k P a$ & $u_{f}: k P a$ & $\varepsilon_{\mathrm{af}}: \%$ & $M$ & $\phi:^{\circ}$ \\
\hline \multirow[t]{6}{*}{ KM20 } & 100 & $134 \cdot 16$ & $189 \cdot 47$ & 23 & $18 \cdot 0$ & $1 \cdot 2496$ & $30 \cdot 73$ \\
\hline & 150 & $169 \cdot 40$ & $211 \cdot 20$ & 51 & $17 \cdot 5$ & & \\
\hline & 200 & $199 \cdot 01$ & 258.02 & 83 & $13 \cdot 0$ & & \\
\hline & 250 & 265.09 & $309 \cdot 28$ & 88 & $20 \cdot 0$ & & \\
\hline & 300 & $290 \cdot 10$ & $360 \cdot 31$ & 124 & $17 \cdot 0$ & & \\
\hline & 400 & $367 \cdot 76$ & $464 \cdot 29$ & 187 & $20 \cdot 0$ & & \\
\hline \multirow[t]{6}{*}{ KM25 } & 100 & $106 \cdot 27$ & $141 \cdot 82$ & 39 & $12 \cdot 5$ & $1 \cdot 1448$ & $28 \cdot 83$ \\
\hline & 150 & $156 \cdot 22$ & $153 \cdot 67$ & 45 & $18 \cdot 0$ & & \\
\hline & 200 & $173 \cdot 88$ & $206 \cdot 65$ & 95 & $10 \cdot 5$ & & \\
\hline & 250 & $219 \cdot 54$ & 250.63 & 114 & $17 \cdot 0$ & & \\
\hline & 300 & $257 \cdot 86$ & 278.57 & 134 & $11 \cdot 5$ & & \\
\hline & 400 & $337 \cdot 70$ & $401 \cdot 11$ & 196 & $19 \cdot 0$ & & \\
\hline \multirow[t]{6}{*}{ KM35 } & 100 & $87 \cdot 92$ & $113 \cdot 75$ & 47 & $18 \cdot 5$ & 1.0996 & $27 \cdot 75$ \\
\hline & 150 & $115 \cdot 77$ & $134 \cdot 30$ & 79 & $20 \cdot 0$ & & \\
\hline & 200 & $195 \cdot 44$ & $211 \cdot 33$ & 75 & $16 \cdot 5$ & & \\
\hline & 250 & $211 \cdot 59$ & $226 \cdot 77$ & 114 & $16 \cdot 0$ & & \\
\hline & 300 & $222 \cdot 80$ & $239 \cdot 41$ & 154 & $10 \cdot 0$ & & \\
\hline & 400 & $317 \cdot 19$ & $351 \cdot 56$ & 200 & $14 \cdot 5$ & & \\
\hline \multirow[t]{6}{*}{ KM55 } & 100 & 78.69 & 89.07 & 47 & $12 \cdot 5$ & 1.0300 & 26.02 \\
\hline & 150 & $98 \cdot 61$ & $112 \cdot 82$ & 89 & $19 \cdot 0$ & & \\
\hline & 200 & $159 \cdot 46$ & $160 \cdot 38$ & 94 & $9 \cdot 5$ & & \\
\hline & 250 & $198 \cdot 24$ & $207 \cdot 72$ & 121 & $14 \cdot 5$ & & \\
\hline & 300 & 223.05 & $231 \cdot 16$ & 149 & $10 \cdot 5$ & & \\
\hline & 400 & $307 \cdot 13$ & $309 \cdot 40$ & 196 & $16 \cdot 5$ & & \\
\hline
\end{tabular}

clay contents $\left(C_{\mathrm{L}} \%\right)$ for the kaolin samples is rather strong at 0.931 and the proposed correlation equation is

5. $\frac{\lambda_{\mathrm{NCL}}}{\lambda_{\mathrm{CSL}}}=0.500+0.017 \times C_{\mathrm{L}} \%$

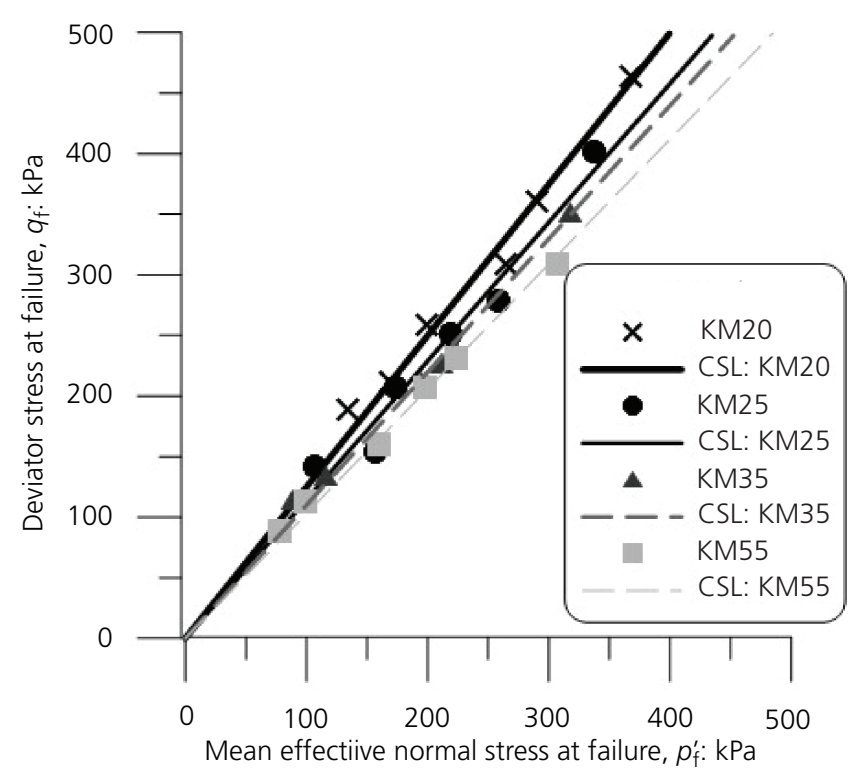

Figure 10. CSLs of tested kaolin samples
Distinguishing between clay-like and sand-like soil behaviours through plasticity index $\left(P_{1}\right)$

A sand-like behaviour is observed from the reconstituted kaolin soils of KM20 and KM25, characterised by their lower $P_{\mathrm{I}}$ values of 7 and $11 \%$, respectively, as well as their CSL and NCL being non-parallel (see Figure 8). In the event that the method of Boulanger and Idriss (2006), which was developed for distinguishing clay-like $\left(P_{\mathrm{I}}\right.$ greater

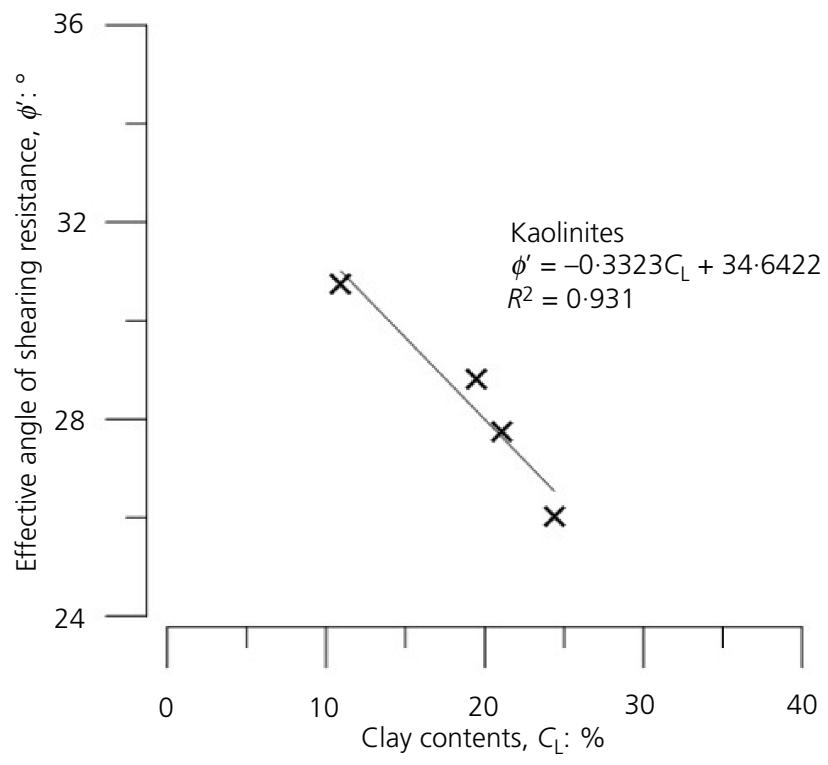

Figure 11. Relationship between clay content and effective angle of internal friction 
Behaviour of $\mathrm{MH}$ silts with varying

plasticity indices

Wong, Ong and Robinson

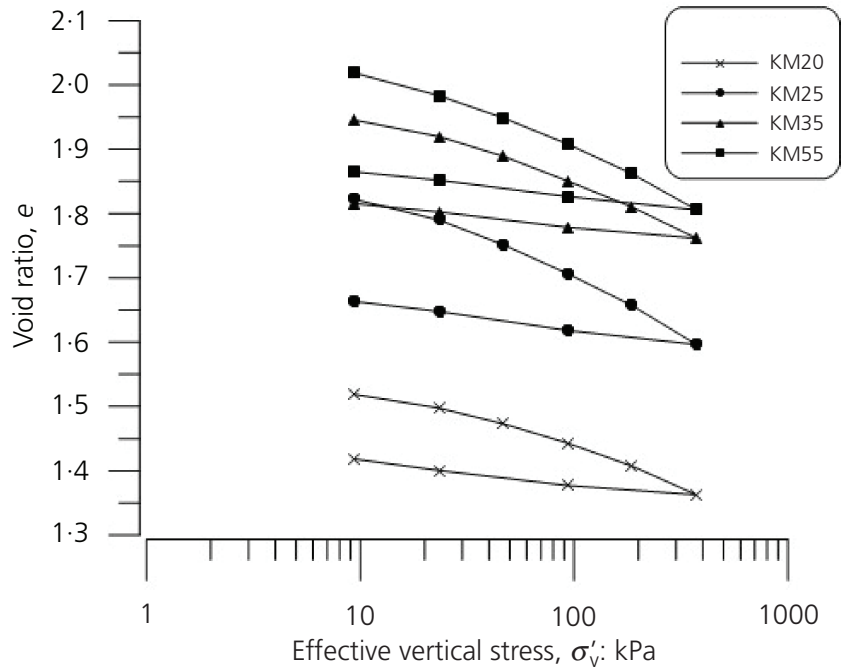

Figure 12. Stress-void relationship during 1D consolidation tests

Table 5. Results of 1D consolidation tests

$\begin{array}{lcc}\text { Sample } & \boldsymbol{\lambda} & \boldsymbol{\kappa} \\ \text { KM20 } & 0.148 & 0.035 \\ \text { KM25 } & 0.201 & 0.042 \\ \text { KM35 } & 0.160 & 0.036 \\ \text { KM55 } & 0.186 & 0.037\end{array}$

than or equal to $7 \%$ ) and sand-like $\left(P_{\mathrm{I}}\right.$ smaller than $7 \%$ ) behaviours of silt based on $P_{\mathrm{I}}$, was applied to the high-plasticity silt $(\mathrm{MH})$ of KM20 and KM25, then KM20 and KM25 would be 'incorrectly' classified as having a clay-like behaviour.

To evaluate further the reliability of the original work of Boulanger and Idriss (2006) on $\mathrm{MH}$, various $P_{\mathrm{I}}$ and $L_{\mathrm{L}}$ data

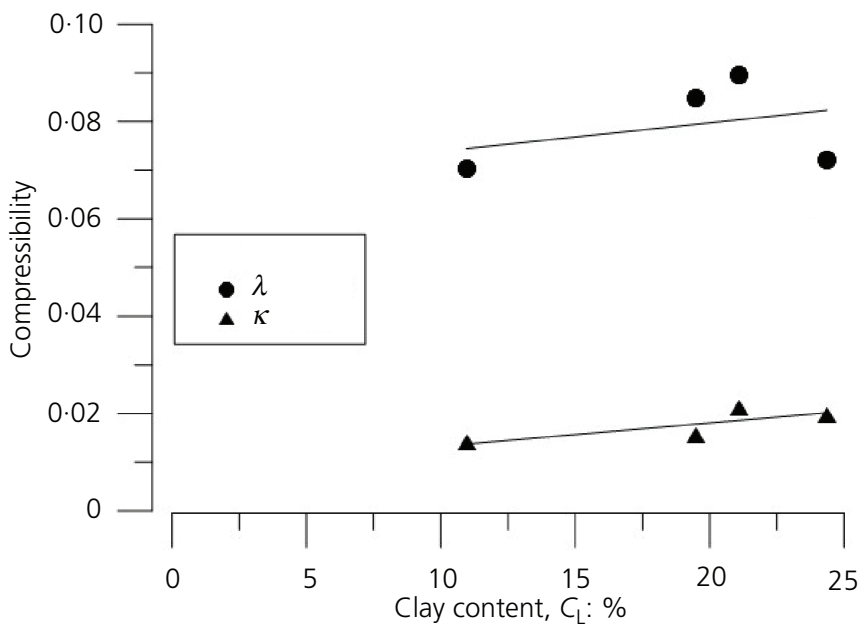

Figure 13. Relationship between clay content and compressibility
Table 6. Gradients of compression lines of NCLs and CSLs

$\begin{array}{lccc}\text { Sample } & \lambda_{\text {NCL }} & \lambda_{\text {CSL }} & \lambda_{\text {NCL }} / \lambda_{\text {CSL }} \\ \text { KM20 } & 0.09354 & 0.13324 & 0.702 \\ \text { KM25 } & 0.08163 & 0.10117 & 0.807 \\ \text { KM35 } & 0.10887 & 0.12863 & 0.846 \\ \text { KM55 } & 0.10484 & 0.11055 & 0.948\end{array}$

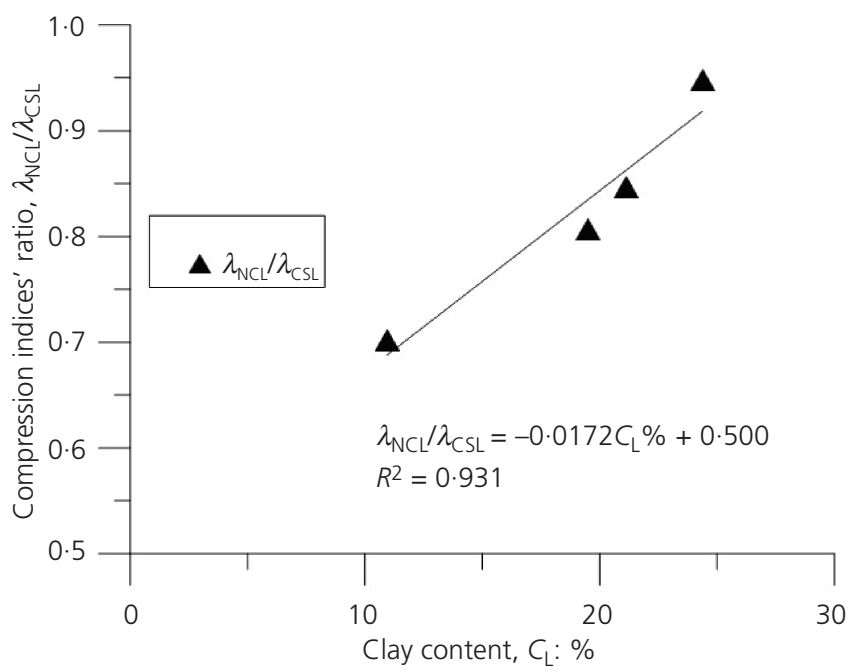

Figure 14. Relationship between compression indices' ratio and clay content

points obtained from well-established papers (see Table 7) are subsequently used to develop Figure 15 together with the classification rules for sand-like and clay-like behaviours as reported by Boulanger and Idriss (2004). As illustrated in Figure 15, apparently, some of the well-documented sand-like soils are lying slightly above the $P_{\mathrm{I}}=7 \%$ boundary suggested by Boulanger and Idriss (2006), which evidently demonstrates the conflict in trying to categorise the well-documented sand-like data to be within the $P_{\mathrm{I}}=7 \%$ boundary. Therefore, it is now proposed that the boundary for describing sand-like behaviour soils be raised from $P_{\mathrm{I}}=7 \%$ (Boulanger and Idriss, 2006) to $P_{\mathrm{I}}=13 \%$ so that the well-documented data points (see Table 7) for soils with a sand-like behaviour can be fulfilled, including that of KM20 ( $P_{\mathrm{I}}=$ $7 \%)$ and $\operatorname{KM} 25\left(P_{\mathrm{I}}=11 \%\right)$, whose sand-like behaviour is clearly demonstrated in Figure 8 . The boundary $P_{\mathrm{I}}=13 \%$ is also supported by Nocilla et al. (2006), who conducted reliable triaxial compression tests on Italian silts. In their work, the samples with clay contents of $4 \%\left(L_{\mathrm{L}}=37 \%\right.$ and $\left.P_{\mathrm{I}}=13 \%\right)$ and $8 \%\left(L_{\mathrm{L}}=34 \%\right.$ and $P_{\mathrm{I}}=13 \%$ ) had evidently demonstrated a sand-like behaviour as the effective stress paths showed an initially contractive response (due to increase in pore pressure) followed by a transition to an incrementally dilative response (due to decrease in pore pressure).

Finally, a threshold of $P_{\mathrm{I}}$ greater than $13 \%$ is now suggested for soils behaving in a clay-like manner. This would then include the 
Table 7. Documented Atterberg limits for soils with sand-like and clay-like behaviours (continued on next page)

\begin{tabular}{|c|c|c|c|c|c|c|c|}
\hline \multicolumn{2}{|c|}{ Soil name } & $\begin{array}{l}\text { Soil classification, ASTM } \\
\text { D } 2487 \text { (ASTM, 2000) }\end{array}$ & $\begin{array}{l}L_{\mathrm{L}}: \\
\%\end{array}$ & $\begin{array}{l}P_{1}: \\
\%\end{array}$ & & \multirow[t]{2}{*}{$\begin{array}{l}\text { Categories and } \\
\text { evidence }\end{array}$} & \multirow[t]{2}{*}{ References } \\
\hline \multicolumn{5}{|c|}{ Cohesive or clay-like behaviour } & & & \\
\hline 1 & B6 marine clay - James Bay & $C L$ & 37 & 13 & $\begin{array}{l}\text { Triaxial and direct } \\
\text { simple shear }\end{array}$ & Cohesive, Figure 9 & $\begin{array}{l}\text { Ladd (1991); Boulanger } \\
\text { and Idriss (2006) }\end{array}$ \\
\hline 2 & Natural London Clay, $5 \cdot 2 \mathrm{~m} \mathrm{BGL}$ & $\mathrm{CH}$ & 69 & 44 & HCA stress path & C3, Figure 4 & Nishimura et al. (2007) \\
\hline 3 & $\begin{array}{l}\text { Natural London Clay, } 10.5 \text { m } \\
\text { BGL }\end{array}$ & $\mathrm{CH}$ & 70 & 44 & HCA stress path & C3, Figure 4 & Nishimura et al. (2007) \\
\hline 4 & Speswhite kaolin & $\mathrm{MH}$ & 62 & 30 & Triaxial & $\begin{array}{l}\text { C3, p. } 8 \text {, column } 2 \text {, } \\
\text { line } 4-\text { p. } 9 \text {, } \\
\text { column } 1 \text {, line } 1\end{array}$ & Georgiannou et al. (1990) \\
\hline 5 & Aeolian silt & $C L$ & 37 & 18 & Triaxial & C3, Figures 8-13 & Cui and Delage (1996) \\
\hline 6 & Sleech silt (3 m depth) & $\mathrm{CH}$ & 58 & 36 & $\begin{array}{r}\text { Triaxial and 1D } \\
\text { consolidation }\end{array}$ & $\begin{array}{c}\text { (3, Figure 3(a); } \\
\text { (1, Figure } 2\end{array}$ & Lehane (2003) \\
\hline 7 & Sleech silt (6 m depth) & $\mathrm{CH}$ & 70 & 48 & $\begin{array}{r}\text { Triaxial and 1D } \\
\text { consolidation }\end{array}$ & $\begin{array}{c}\text { C3, Figure 3(a); } \\
\text { C1, Figure } 2\end{array}$ & Lehane (2003) \\
\hline 8 & Sub-Apennine Blue Clays, By & $\mathrm{CL}$ & 49 & $26 \cdot 4$ & $\begin{array}{l}\text { Triaxial and 1D } \\
\text { consolidation }\end{array}$ & C3, Figure 13 & Cotecchia et al. (2007) \\
\hline 9 & Sub-Apennine Blue Clays, Bg & $\mathrm{CL}$ & $51 \cdot 1$ & $27 \cdot 7$ & $\begin{array}{c}\text { Triaxial and 1D } \\
\text { consolidation }\end{array}$ & C3, Figure 13 & Cotecchia et al. (2007) \\
\hline 10 & Sub-Apennine Blue Clays, P9 & $\mathrm{CH}$ & $69 \cdot 3$ & $38 \cdot 4$ & $\begin{array}{r}\text { Triaxial and 1D } \\
\text { consolidation }\end{array}$ & C1, Figure 5 & Cotecchia et al. (2007) \\
\hline 11 & Sub-Apennine Blue Clays, P19 & $\mathrm{CL}$ & $51 \cdot 8$ & $28 \cdot 8$ & $\begin{array}{r}\text { Triaxial and 1D } \\
\text { consolidation }\end{array}$ & C1, Figure 5 & Cotecchia et al. (2007) \\
\hline 12 & Sub-Apennine Blue Clays, P25 & $\mathrm{CH}$ & 65 & 35 & $\begin{array}{r}\text { Triaxial and 1D } \\
\text { consolidation }\end{array}$ & C3, Figure 11 & Cotecchia et al. (2007) \\
\hline 13 & Sub-Apennine Blue Clays, P33 & $\mathrm{CH}$ & $53 \cdot 4$ & $27 \cdot 5$ & $\begin{array}{r}\text { Triaxial and 1D } \\
\text { consolidation }\end{array}$ & C1, Figure 5 & Cotecchia et al. (2007) \\
\hline 14 & Sherbrooke laminated clay & $C L$ & 45 & 18 & Triaxial & C3, Figure $7(a)$ & Long (2006) \\
\hline 15 & Compacted clayey silt fill & $\mathrm{CL}$ & $45 \cdot 6$ & $20 \cdot 1$ & Triaxial & $\begin{array}{l}\text { C3, Figures } 5(c) \\
\text { and } 5(d)\end{array}$ & Almeida et al. (2012) \\
\hline 16 & Bengawan Solo fill D1 & $\mathrm{MH}$ & 54 & 18 & Triaxial & $\mathrm{C} 3$, Figure 8 & Mountassir et al. (2011) \\
\hline 17 & Bengawan Solo fill D2 & $\mathrm{MH}$ & 53 & 16 & Triaxial & C3, Figure 8 & Mountassir et al. (2011) \\
\hline 18 & $\begin{array}{l}\text { Mixtures of kaolin, sodium } \\
\text { bentonite and London Clay }\end{array}$ & $C L$ & 28 & 18 & Triaxial & C3, Figure 6 & Cunningham et al. (2003) \\
\hline 19 & Mexico Clay - oven-dried & $\mathrm{MH}$ & 93 & 23 & 1D consolidation & C1, Figure 16 & Mesri et al. (1975) \\
\hline 20 & Residual London Clay & $\mathrm{CH}$ & 80 & 51 & Triaxial & Cohesive, Figure 11 & Skempton (1985) \\
\hline 21 & KM35 & $\mathrm{MH}$ & 62 & 16 & Triaxial & $C 2$, Figure 5 & This paper \\
\hline 22 & KM55 & $\mathrm{MH}$ & 64 & 15 & Triaxial & $C 2$, Figure 5 & This paper \\
\hline 23 & Grey organic clay & $C L$ & 38 & 19 & Triaxial & C3, Figure 11 & Long and O'Riordan (2001) \\
\hline 24 & Bolkin silt & $C L$ & $29 \cdot 4$ & $15 \cdot 6$ & Triaxial & C3, Figure 1 & Wang et al. (2002) \\
\hline 25 & Hong Kong marine deposits C4 & $\mathrm{CL}$ & 60 & 32 & $\begin{array}{r}\text { Triaxial and 1D } \\
\text { consolidation }\end{array}$ & C3, Figure 12 & Yin (1999) \\
\hline 26 & Kaolin soil 68-32 & $\mathrm{ML}$ & 47 & 17 & $\begin{array}{r}\text { Triaxial and 1D } \\
\text { consolidation }\end{array}$ & C3, Figure 6 & Anantanasakul et al. (2012) \\
\hline 27 & MSM10-3 & $C L$ & 35 & 15 & 1D consolidation & C1, Figure 8 & Biscontin et al. (2007) \\
\hline 28 & MSM10-6 & $C L$ & 38 & 19 & 1D consolidation & C1, Figure 8 & Biscontin et al. (2007) \\
\hline 29 & MSM10-14 & ML & 49 & 20 & 1D consolidation & C1, Figure 8 & Biscontin et al. (2007) \\
\hline 30 & MSM10-43 & $\mathrm{CL}$ & 42 & 22 & 1D consolidation & C1, Figure 8 & Biscontin et al. (2007) \\
\hline 31 & MSM10-48 & $C L$ & 36 & 13 & 1D consolidation & C1, Figure 8 & Biscontin et al. (2007) \\
\hline 32 & MSM10-52 & $C L$ & 38 & 19 & 1D consolidation & C1, Figure 8 & Biscontin et al. (2007) \\
\hline 33 & MSgM1-2 & $C L$ & 34 & 14 & 1D consolidation & C1, Figure 8 & Biscontin et al. (2007) \\
\hline 34 & MSgM1-3 & $C L$ & 32 & 13 & 1D consolidation & C1, Figure 8 & Biscontin et al. (2007) \\
\hline 35 & MSgM1-10 & $\mathrm{MH}$ & 56 & 24 & 1D consolidation & C1, Figure 8 & Biscontin et al. (2007) \\
\hline 36 & MSgM1-22 & $\mathrm{MH}$ & 62 & 28 & 1D consolidation & C1, Figure 8 & Biscontin et al. (2007) \\
\hline 37 & MSgM1-22b & $\mathrm{MH}$ & 62 & 28 & 1D consolidation & C1, Figure 8 & Biscontin et al. (2007) \\
\hline 38 & MSgM1-24 & $C L$ & 41 & 19 & 1D consolidation & C1, Figure 8 & Biscontin et al. (2007) \\
\hline 39 & MSgM2-11mb & $M L$ & 46 & 15 & 1D consolidation & C1, Figure 8 & Biscontin et al. (2007) \\
\hline 40 & Completely decomposed tuff & $M L$ & 43 & 14 & $\begin{array}{l}\text { Triaxial - } \\
\text { consolidation }\end{array}$ & C2, Figure 3(a) & Chiu and Ng (2012) \\
\hline 41 & Natural soil & $C L$ & 38 & 16 & Triaxial & C1, Figure 3 & Cetin and Soylemez (2004) \\
\hline 42 & Nancy North-west silt & $\mathrm{MH}$ & 56 & 25 & Triaxial & C3, Figure 2 & Ltifi et al. (2014) \\
\hline
\end{tabular}


Table 7. Continued

\begin{tabular}{|c|c|c|c|c|c|c|c|}
\hline \multicolumn{2}{|c|}{ Soil name } & \multirow{2}{*}{$\begin{array}{c}\text { Soil classification, ASTM } \\
\text { D } 2487 \text { (ASTM, 2000) } \\
\text { ML }\end{array}$} & \multirow{2}{*}{$\begin{array}{c}L_{\mathrm{L}}: \\
\% \\
45\end{array}$} & \multirow{2}{*}{$\begin{array}{c}P_{1}: \\
\% \\
15\end{array}$} & \multirow{2}{*}{$\begin{array}{c}\text { Tests } \\
\text { Monotonic } \\
\text { simple shear }\end{array}$} & \multirow{2}{*}{$\begin{array}{c}\text { Categories and } \\
\text { evidence }\end{array}$} & \multirow{2}{*}{$\begin{array}{c}\text { References } \\
\text { Mao and Fahey (2003) }\end{array}$} \\
\hline 43 & Gorgon muddy silt & & & & & & \\
\hline 44 & Mud cake in silt & $\mathrm{CH}$ & $58 \cdot 5$ & $28 \cdot 8$ & Triaxial & C3, Figure 5 & Zhang et al. (2009) \\
\hline 45 & In situ soil in silt & $\mathrm{CH}$ & $52 \cdot 6$ & $25 \cdot 3$ & Triaxial & C3, Figure 5 & Zhang et al. (2009) \\
\hline 46 & Mud cake in clay & $C L$ & $43 \cdot 9$ & 20 & Triaxial & C3, Figure 6 & Zhang et al. (2009) \\
\hline 47 & Italian silt (clay content 25\%) & $\mathrm{CL}$ & 46 & 22 & Triaxial & C3, Figure 7 & Nocilla et al. (2006) \\
\hline 48 & Italian silt (clay content 45\%) & $\mathrm{MH}$ & 60 & 33 & Triaxial & C3, Figure 7 & Nocilla et al. (2006) \\
\hline \multicolumn{8}{|c|}{ Cohesionless or sand-like behaviour } \\
\hline 1 & KM20 & $\mathrm{MH}$ & 51 & 7 & Triaxial & S2, Figure 5 & This paper \\
\hline 2 & KM25 & $\mathrm{MH}$ & 59 & 11 & Triaxial & C2, Figure 5 & This paper \\
\hline 3 & $\begin{array}{l}\text { Residual soil from } \\
\text { Botucatu Sandstone }\end{array}$ & CL-ML & 20 & 6 & $\begin{array}{l}\text { Triaxial and 1D } \\
\text { consolidation }\end{array}$ & S1, Figure 5 & Ferreira and Bica (2006) \\
\hline 4 & Brown laminated clay & $\mathrm{ML}$ & 35 & 12 & Triaxial & S3, Figure 11 & $\begin{array}{l}\text { Long and O'Riordan } \\
\text { (2001) }\end{array}$ \\
\hline 5 & MRV silt & $C L$ & 28 & 6 & Triaxial & S3, Figure 6 & Wang et al. (2011) \\
\hline 6 & Silt at Moss Landing B7-03 & $M L$ & 36 & 11 & Cyclic triaxial & S4, Figure 11 & Boulanger et al. (1998) \\
\hline 7 & Silt at Moss Landing B7-03 & $\mathrm{ML}$ & 31 & 6 & Cyclic triaxial & S4, Figure 11 & Boulanger et al. (1998) \\
\hline 8 & Delhi silt S60M40 & $\mathrm{ML}$ & $27 \cdot 5$ & $4 \cdot 5$ & Triaxial & S3, Figure 15 & Usmani et al. (2011) \\
\hline 9 & Delhi silt S20M80 & $C L$ & 30 & 8 & Triaxial & S3, Figure 15 & Usmani et al. (2011) \\
\hline 10 & Kaolin soil 45-55 & CL-ML & 28 & 7 & Triaxial & S3, Figure 6 & $\begin{array}{l}\text { Anantanasakul et al. } \\
\text { (2012) }\end{array}$ \\
\hline 11 & Kaolin soil 24-76 & CL-ML & 20 & 4 & Triaxial & S3, Figure 6 & $\begin{array}{l}\text { Anantanasakul et al. } \\
\text { (2012) }\end{array}$ \\
\hline 12 & Manglerud quick clay & $\mathrm{ML}$ & 27 & 8 & Direct shear & S3, Figure 9 & $\begin{array}{l}\text { Bjerrum and Landva } \\
\text { (1966) }\end{array}$ \\
\hline 13 & Adapazari silt & $C L$ & $30 \cdot 5$ & $5 \cdot 5$ & Triaxial & S3, Figure 15 & Arel and Onalp (2012) \\
\hline 14 & Limestone powder & CL-ML & 24 & 6 & Triaxial & $\begin{array}{l}\text { S3, Figures } 5 \\
\text { and } 6\end{array}$ & Hyde et al. (2006) \\
\hline 15 & Norwegian glaciomarine silt & $C L$ & 33 & 12 & Triaxial & S3, Figure 9 & Long et al. (2010) \\
\hline 16 & Italian silt (clay content 4\%) & $C L$ & 34 & 12 & Triaxial & S3, Figure 7 & Nocilla et al. (2006) \\
\hline 17 & Italian silt (clay content ৪\%) & $C L$ & 37 & 13 & Triaxial & S3, Figure 7 & Nocilla et al. (2006) \\
\hline 18 & Fraser River silt & $\mathrm{CL}$ & $30 \cdot 4$ & $4 \cdot 1$ & $\begin{array}{l}\text { Cyclic direct } \\
\text { simple shear }\end{array}$ & S4, Figure 5 & $\begin{array}{l}\text { Wijewickreme and Sanin } \\
\text { (2010) }\end{array}$ \\
\hline 19 & Blended silt mixture 1 & $M L$ & 26 & 0 & Triaxial & S3, Figure 9 & $\begin{array}{l}\text { Boulanger and Idriss } \\
\text { (2006) }\end{array}$ \\
\hline 20 & Blended silt mixture 2 & $\mathrm{ML}$ & 30 & 4 & Triaxial & S3, Figure 9 & $\begin{array}{l}\text { Boulanger and Idriss } \\
\text { (2006) }\end{array}$ \\
\hline 21 & Blended silt mixture 3 & $\mathrm{ML}$ & $36 \cdot 5$ & $10 \cdot 5$ & Triaxial & $\begin{array}{l}\text { S2, Figure } 8 \\
\text { (replotted } \\
\text { including all } \\
\text { scatter points) }\end{array}$ & $\begin{array}{l}\text { Boulanger and Idriss } \\
\text { (2006) }\end{array}$ \\
\hline
\end{tabular}

Extracted from Boulanger and Idriss (2004)

BGL, below ground level; HCA, hollow cylinder apparatus

S1: sand-like; sands have a small enough compressibility that their void ratio does not change significantly as the effective consolidation stress is increased

S2: sand-like; the slope of the CSL in void ratio (e) against the logarithm of mean effective stress $\left(p^{\prime}\right)$ space is different from the slope of virgin consolidation line

S3: sand-like; the effective stress paths for sand in undrained monotonic shearing often show an initially contractive response (positive pore pressure increments since volume change is zero) followed by a transition to an incrementally dilative response (decreases in pore pressure)

S4: sand-like; during the undrained cyclic stress-strain loops, the sands develop a very flat middle portion (where the shear stiffness is essentially zero) that is observed for sands after the excess pore pressure reaches a limiting value, which corresponds to the sample temporarily having zero effective stress $\left(r_{\mathrm{u}}=100 \%\right)$ C1: clay-like; clays have a large enough compressibility that their void ratio is highly dependent on the effective consolidation stress and consolidation stress history C2: clay-like; the slope of the CSL in void ratio (e) against the logarithm of the mean effective stress $\left(p^{\prime}\right)$ space is the same as the slope of virgin consolidation line C3: clay-like; the effective stress paths for clay in undrained monotonic shearing not following S3 behaviour

C4: clay-like; clays show a very plastic stress-strain response (nearly constant shear stress after yield) for $O_{C R}$ of $1-8$, while sands show a range of strain softening to strain hardening behaviour that depended on the sand's relative density and confining stress

C5: clay-like; during the undrained cyclic stress-strain loops, the clays do not develop a very flat middle portion (where the shear stiffness is essentially zero) that is observed for sands after the excess pore pressure reaches a limiting value, which corresponds to the sample temporarily having zero effective stress $\left(r_{u}=100 \%\right)$ 


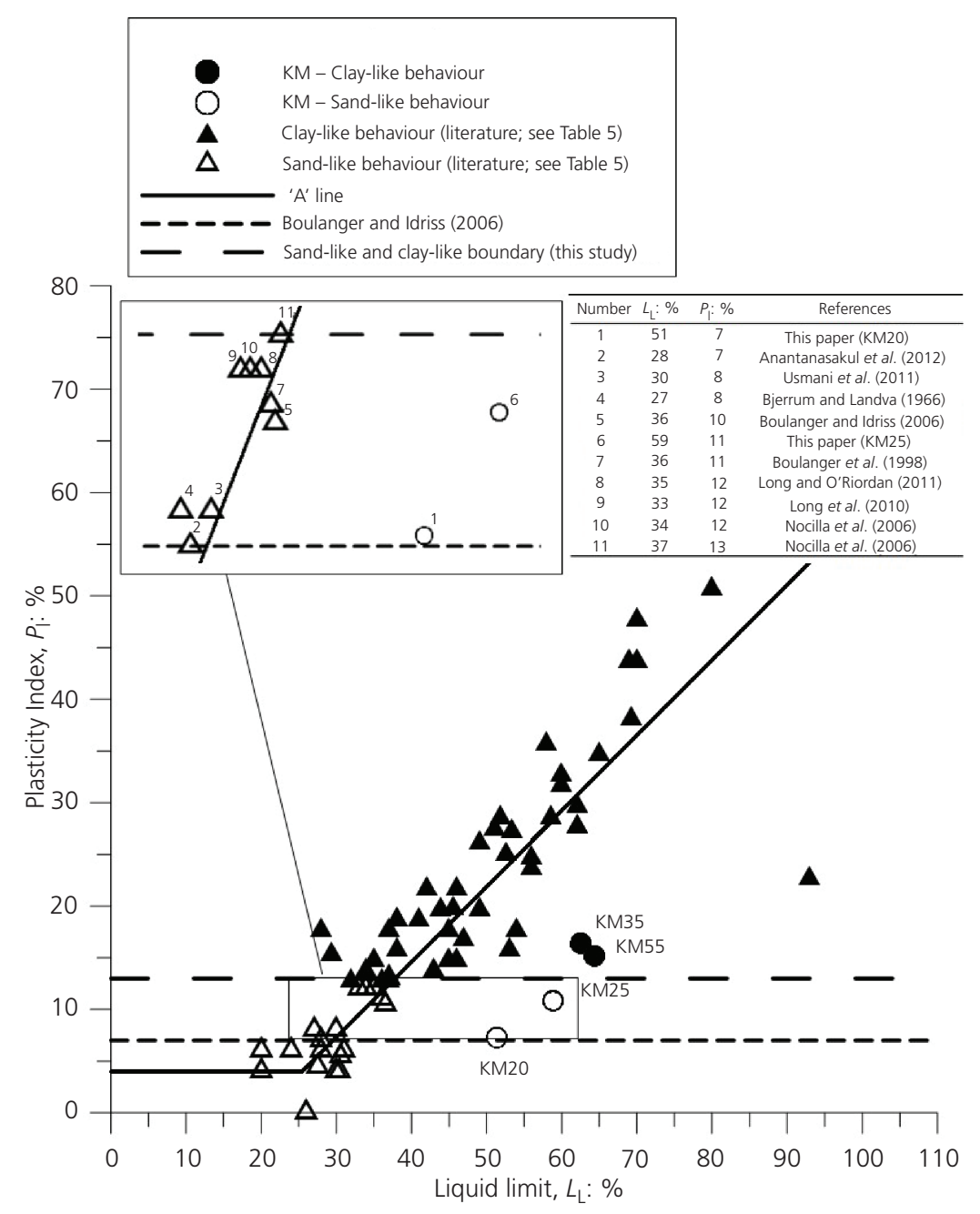

Figure 15. Boundaries for clay-like and sand-like behaviours (this study and others)

well-documented soils sourced from the literature summarised in Table 7, as well as $\operatorname{KM} 35\left(P_{\mathrm{I}}=16 \%\right)$ and $\operatorname{KM} 55\left(P_{\mathrm{I}}=15 \%\right)$ as included in Figure 15. Indeed, Figure 8 evidently shows that the apparent clay-like behaviours of KM35 and KM55 have parallel CSLs and NCLs.

As all the well-documented data points, including those from this study, can be simultaneously included within the newly postulated framework as shown in Figure 15, this study has been proven to be reliable, consistent and beneficial to engineers seeking a less expensive classification method for identifying silt behaviour.

\section{Conclusions}

Reconstituted kaolin samples of high-plasticity silts $(\mathrm{MH})$ with varying clay contents were used to investigate the transitional behaviour of silts. Atterberg limit, dry sieving, hydrometer, CIU and oedometer tests were conducted on these reconstituted samples to characterise the behaviours of the samples in terms of clay-like or sand-like behaviours.
In the $v-\ln p^{\prime}$ space derived from the CIU tests, the gradients of the respective CSLs seem to be approaching the same gradient of the NCLs when the $P_{\mathrm{I}}$ of the reconstituted kaolins increased progressively from KM20 $\left(P_{\mathrm{I}}=7 \%\right), \mathrm{KM} 25\left(P_{\mathrm{I}}=11 \%\right), \mathrm{KM} 35$ $\left(P_{\mathrm{I}}=16 \%\right)$ to KM55 $\left(P_{\mathrm{I}}=15 \%\right)$. KM35 and KM55 demonstrate a clay-like behaviour with $P_{\mathrm{I}}$ values greater than $13 \%$, while KM20 and KM25 exhibit a sand-like behaviour with $P_{\mathrm{I}}$ values smaller than $13 \%$. Therefore, with the support of well-documented soils sourced from the 33 papers summarised in Table 7 and the research work carried out in this paper, thresholds for $(a)$ sand-like and $(b)$ clay-like silts are thus proposed as $(a) P_{\mathrm{I}} \leq 13 \%$ and $(b) P_{\mathrm{I}}>13 \%$, respectively. Based on the newly postulated framework, all the well-documented data points from Table 7 as well as the MH data points from this research can be simultaneously included.

Based on the mentioned important findings of this study, if the values of Atterberg limits are the only available data, silts can then be characterised in terms of sand-like or clay-like behaviours by using the newly proposed framework before an appropriate 
advanced soil model is selected to represent its behaviour. With this knowledge, for example, the modified Cam Clay model may not be wrongly applied to silts with a sand-like behaviour. The results obtained in this study show good reliability when compared to 65 sets of past significant experimental studies derived from 33 established past research papers.

\section{REFERENCES}

Almeida MSS, Filho MGR, Futai MM and Filho MR (2012) Laboratory and in situ studies on a compacted clayey silt fill. Proceedings of the Institution of Civil Engineers - Geotechnical Engineering 165(2): 107-119, http://dx.doi.org/10.1680/geng.10.00050.

Anantanasakul P, Yamamuro JA and Kaliakin VN (2012) Stress-strain and strength characteristics of silt-clay transition soils. Journal of Geotechnical and Geoenvironmental Engineering 138(10): 1257-1265, http://dx.doi. org/10.1061/(ASCE)GT.1943-5606.0000692.

Arel E and Onalp A (2012) Geotechnical properties of Adapazari silt. Bulletin of Engineering Geology and the Environment 71(4): 709-720, http://dx.doi.org/10.1007/s10064-012-0443-6.

ASTM (2000) D 2487: Standard practice for classification of soils for engineering purposes (unified soil classification system). ASTM International, West Conshohocken, PA, USA.

ASTM (2011) D 2435: Standard test methods for one-dimensional consolidation properties of soils using incremental loading. ASTM International, West Conshohocken, PA, USA.

Biscontin G, Cola S, Pestanam JM and Simonini P (2007) Unified compression model for Venice lagoon natural silts. Journal of Geotechnical and Geoenvironmental Engineering 133(8): 932-942, http://dx.doi.org/10.1061/(ASCE)1090-0241(2007)133:8(932).

Bjerrum L and Landva A (1966) Direct simple-shear tests on a Norwegian quick clay. Géotechnique 16(1): 1-20, http://dx.doi.org/10.1680/geot. 1966.16.1.1.

Boulanger R and Idriss IM (2004) Evaluating the Potential for Liquefaction of Cyclic Failure of Silts and Clays. Center for Geotechnical Modeling, University of California, Davis, CA, USA.

Boulanger R and Idriss IM (2006) Liquefaction susceptibility criteria for silts and clays. Journal of Geotechnical and Geoenvironmental Engineering 132(11): 1413-1426, http://dx.doi.org/10.1061/(ASCE) 1090-0241(2006)132:11(1413).

Boulanger RW, Meyers MW, Mejia L and Idriss IM (1998) Behaviour of a fine-grained soil during the Loma Prieta earthquake. Canadian Geotechnical Journal 35(1): 146-158, http://dx.doi.org/10.1139/t97078.

BSI (1990a) BS 1377-2:1990: Methods of test for soils for civil engineering purposes. Classification tests. BSI, London. UK.

BSI (1990b) BS 1377-5:1990: Methods of test for soils for civil engineering purposes. Compressibility, permeability and durability tests. BSI, London. UK.

BSI (1990c) BS 1377-8:1990: Methods of test for soils for civil engineering purposes. Shear strength tests (effective stress). BSI, London. UK

Burland JB (1990) On the compressibility and shear strength of natural clays. Géotechnique 40(3): 329-378, http://dx.doi.org/10.1680/geot. 1990.40.3.329.

Cetin H and Soylemez M (2004) Soil-particle and pore orientations during drained and undrained shear of a cohesive sandy silt-clay soil. Canadian Geotechnical Journal 41(1): 1127-1138, http://dx.doi.org/ 10.1139/t04-055.

Chiu CF and Ng CWW (2012) Coupled water retention and shrinkage properties of a compacted silt under isotropic and deviatoric stress paths. Canadian Geotechnical Journal 49(1): 928-938, http://dx.doi. org/10.1139/t2012-055

Cotecchia F, Cafaro F and Aresta B (2007) Structure and mechanical response of sub-Apennine Blue Clays in relation to their geological and recent loading history. Géotechnique 57(2): 167-180, http://dx. doi.org/10.1680/geot.2007.57.2.167.

Cui YJ and Delage P (1996) Yielding and plastic behaviour of an unsaturated compacted silt. Géotechnique 46(2): 291-311, http://dx. doi.org/10.1680/geot.1996.46.2.291.

Cunningham MR, Ridley AM, Dineen K and Burland JB (2003) The mechanical behaviour of a reconstituted unsaturated silty clay. Géotechnique 53(2): 183-194, http://dx.doi.org/10.1680/geot.2003.53. 2.183 .

Ferreira PM and Bica AVD (2006) Problems in identifying the effects of structure and critical state in soil with transitional behaviour. Géotechnique 56(7): 445-454, http://dx.doi.org/10.1680/geot.2006.56.7.445.

Georgiannou VN, Burland JB and Hight DW (1990) The undrained behaviour of clayey sands in triaxial compression and extension. Géotechnique 40(3): 431-449, http://dx.doi.org/10.1680/geot.1990.40. 3.431 .

Head KH (1998) Effective Stress Tests. Manual of Soil Laboratory Testing. Wiley, Singapore, vol. 3.

Hyde AF, Higuchi T and Yasuhara K (2006) Liquefaction, cyclic mobility, and failure of silt. Journal of Geotechnical and Geoenvironmental Engineering 132(6): 716-735, http://dx.doi.org/10.1061/(ASCE)10900241(2006)132:6(716).

Hyodo M, Yamamoto Y and Sugiyama M (1994) Undrained cyclic behaviour of normally consolidated clay subjected to initial static shear stress. Soils and Foundations 34(4): 1-11, http://doi.org/10. 3208/sandf1972.34.41.

Ishihara K, Tatsuoka, Fumo and Yasuda S (1975) Undrained deformation and liquefaction of sand under cyclic stress. Soils and Foundations 15(1): 29-44, http://doi.org/10.3208/sandf1972.15.29.

Ladd CC (1991) Stability evaluation during staged construction. Journal of Geotechnical and Geoenvironmental Engineering 117(4): 540-615, http://dx.doi.org/10.1061/(ASCE)0733-9410(1991)117:4(540).

Ladd CC, Foott R, Ishihara K, Schlosser F and Poulos HG (1977) Stressdeformation and strength characteristics. In Procedings of 9th International Conference on Soil Mechanics and Foundation Engineering. Japanese Society of Soil Mechanics and Foundation Engineering, Tokyo, Japan, vol. 2, pp. 421-494.

Lambe TW and Whitman RV (1969) Soil Mechanics. Wiley, New York, NY, USA.

Lehane BM (2003) Vertically loaded shallow foundation on soft clayey silt. Geotechnical Engineering 156(1): 17-26, http://dx.doi.org/10. 1680/geng.2003.156.1.17.

Long M (2006) Sample disturbance effects on medium plasticity clay/silt Geotechnical Engineering 159(2): 99-111, http://dx.doi.org/10.1680/ geng.2006.159.2.99.

Long MM and O'Riordan J (2001) Field behaviour of very soft clays at the Athlone embankments. Géotechnique 51(4): 293-309, http://dx. doi.org/10.1680/geot.2001.51.4.293.

Long M, Gudjonsson G, Donohue S and Hagberg K (2010) Engineering characterization of Norwegian glaciomarine silt. Engineering Geology 110(3-4): 51-65, https://doi.org/10.1016/j.enggeo.2009.11.002.

Ltifi M, Abichou T and Tisot JP (2014) Effects of soil aging on mechanical and hydraulic properties of silty soil. Geotechnical and Geological Engineering 32(4): 1101-1108, http://dx.doi.org/10.1007/s10706-0149784-1.

Mao X and Fahey M (2003) Behaviour of calcareous soils in undrained cyclic simple shear. Géotechnique 53(8): 715-727, http://dx.doi.org/ 10.1680/geot.2003.53.8.715.

Mesri G, Rokshsar A and Bohor BF (1975) Composition and compressibility of typical samples of Mexico City clay. Géotechnique 25(3): 527-554, http://dx.doi.org/10.1680/geot.1975.25.3.527.

Mountassir GE, Sanchez M, Romero E and Soemitro RAA (2011) Behaviour of compacted silt use to construct flood embankment. Proceedings of the Institution of Civil Engineers - Geotechnical Engineering 164(3): 195-210, http://dx.doi.org/10.1680/geng.10.00055. 
Geotechnical Research

Volume 4 Issue GR2
Behaviour of $\mathrm{MH}$ silts with varying

plasticity indices

Wong, Ong and Robinson
Nishimura S, Minh NA and Jardine RJ (2007) Shear strength anisotropy of natural London clay. Géotechnique 57(1): 49-62, http://dx.doi.org/10. 1680/geot.2007.57.1.49.

Nocilla A and Coop MR (2008) The behaviour of sub-soils from the Po Rivers embankments: an example of transitional behaviour in natural soils. Italian Geotechnical Journal 42(1): 49-58.

Nocilla A, Coop MR and Colleselli F (2006) The mechanics of an Italian silt: an example of 'transitional' behaviour. Géotechnique 56(4): 261-271, http://dx.doi.org/10.1680/geot.2006.56.4.261.

Pillai R, Robinson RG and Boominathan A (2011) Effect of microfabric on undrained static and cyclic behaviour or kaolin clay. Journal of Geotechnical and Geoenvironmental Engineering 137(4): 421-429, http://dx.doi.org/10.1061/(ASCE)GT.1943-5606.0000442.

Skempton AW (1953) The colloidal 'activity' of clays. Proceedings of the 3rd International Conference on Soil Mechanics, Zurich, Switzerland, vol. 1, pp. 57-61.

Skempton AW (1985) Residual strength of clays in landslides, folded strata and the laboratory. Géotechnique 35(1): 3-18, http://dx.doi.org/ 10.1680/geot.1985.35.1.3.

Usmani A, Ramana GV and Sharma KG (2011) Experimental evaluation of shear-strength behaviour of Delhi silt under static loading conditions. Journal of Materials in Civil Engineering 23(5): 533-541, http://dx. doi.org/10.1061/(ASCE)MT.1943-5533.0000203.
Wang S and Luna R (2012) Monotonic behaviour of Mississippi River Valley silt in triaxial compression. Journal of Geotechnical and Geoenvironmental Engineering 138(4): 516-525, http://dx.doi.org/10. 1061/(ASCE)GT.1943-5606.0000603.

Wang Q, Pufahl DE and Fredlund DG (2002) A study of critical state on an unsaturated silty soil. Canadian Geotechnical Journal 39(1): 213-218, http://dx.doi.org/10.1139/t01-086.

Wang S, Luna R and Stephenson RW (2011) A slurry consolidation approach to reconstitute low-plasticity silt specimens for laboratory triaxial testing. Geotechnical Testing Journal 34(4): 1-9, https://doi. org/10.1520/GTJ103529.

Wijewickreme D and Sanin M (2010) Postcyclic reconsolidation strains in low-plastic Fraser River silt due to dissipation of excess pore-water pressures. Journal of Geotechnical and Geoenvironmental Engineering 136(10): 1347-1357, http://dx.doi.org/10.1061/(ASCE) GT.1943-5606.0000349.

Yin J (1999) Properties and behaviour of Hong Kong marine deposits with different clay contents. Canadian Geotechnical Journal 36(1): 1085-1095, http://dx.doi.org/10.1139/t99-068.

Zhang ZM, Yu J, Zhang GX and Zhou XM (2009) Test study on the characteristics of mudcakes and in situ soils around bored piles. Canadian Geotechnical Journal 46(1): 241-255, http://dx.doi.org/10. 1139/T08-119.

\section{How can you contribute?}

To discuss this paper, please submit up to 500 words to the editor at journals@ice.org.uk. Your contribution will be forwarded to the author(s) for a reply and, if considered appropriate by the editorial board, it will be published as a discussion in a future issue of the journal. 